\title{
Yield gaps, nutrient use efficiencies and response to fertilisers by maize across heterogeneous smallholder farms of western Kenya
}

\author{
P. Tittonell • B. Vanlauwe $\cdot$ M. Corbeels • \\ K. E. Giller
}

Received: 24 October 2007 / Accepted: 2 June 2008 / Published online: 26 August 2008

(C) The Author(s) 2008. This article is published with open access at Springerlink.com

\begin{abstract}
The need to promote fertiliser use by African smallholder farmers to counteract the current decline in per capita food production is widely recognised. But soil heterogeneity results in variable responses of crops to fertilisers within single farms. We used existing databases on maize production
\end{abstract}

Editorial Responsibility: Len Wade

P. Tittonell • K. E. Giller

Plant Production Systems, Department of Plant Sciences,

Wageningen University,

P. O. Box 430, Haarweg 333,

6700 AK Wageningen, The Netherlands

P. Tittonell $\cdot$ B. Vanlauwe $\cdot$ M. Corbeels

Tropical Soil Biology and Fertility Institute of the

International Centre for Tropical Agriculture (TSBF-CIAT),

United Nations Avenue, P. O. Box 30677, Nairobi, Kenya

M. Corbeels

UMR System, Centre de Coopération Internationale en

Recherche Agronomique pour le Développement (CIRAD),

SupAgro, Bâtiment 27, 2 place Viala,

34060 Montpellier Cedex 2, France

P. Tittonell $(\bowtie)$

Unité de Recherche Systèmes de Culture Annuels,

CIRAD-Persyst,

TA B 102/02 Avenue Agropolis,

34398-Montpellier cedex 5, France

e-mail: pablo.tittonell@cirad.fr under farmer (F-M) and researcher management (R-M) to analyse the effect of soil heterogeneity on the different components of nutrient use efficiency by maize growing on smallholder farms in western Kenya: nutrient availability, capture and conversion efficiencies and crop biomass partitioning. Subsequently, we used the simple model QUEFTS to calculate nutrient recovery efficiencies from the R-M plots and to calculate attainable yields with and without fertilisers based on measured soil properties across heterogeneous farms. The yield gap of maize between F-M and R-M varied from 0.5 to $3 \mathrm{t}$ grain $\mathrm{ha}^{-1}$ season $^{-1}$ across field types and localities. Poor fields under R-M yielded better than F-M, even without fertilisers. Such differences, of up to $1.1 \mathrm{t} \mathrm{ha}^{-1}$ greater yields under R-M conditions are attributable to improved agronomic management and germplasm. The relative response of maize to $\mathrm{N}-\mathrm{P}-\mathrm{K}$ fertilisers tended to decrease with increasing soil quality (soil $\mathrm{C}$ and extractable P), from a maximum of 4.4-fold to -0.5 fold relative to the control. Soil heterogeneity affected resource use efficiencies mainly through effects on the efficiency of resource capture. Apparent recovery efficiencies varied between 0 and $70 \%$ for $\mathrm{N}, 0$ and $15 \%$ for $\mathrm{P}$, and 0 to $52 \%$ for $\mathrm{K}$. Resource conversion efficiencies were less variable across fields and localities, with average values of $97 \mathrm{~kg} \mathrm{DM} \mathrm{kg}^{-1} \mathrm{~N}$, $558 \mathrm{~kg} \mathrm{DM} \mathrm{kg}^{-1} \mathrm{P}$ and $111 \mathrm{~kg} \mathrm{DM} \mathrm{kg}^{-1} \mathrm{~K}$ taken up. 
Using measured soil chemical properties QUEFTS over-estimated observed yields under F-M, indicating that variable crop performance within and across farms cannot be ascribed solely to soil nutrient availability. For the R-M plots QUEFTS predicted positive crop responses to application of $30 \mathrm{~kg} \mathrm{P} \mathrm{ha}{ }^{-1}$ and $30 \mathrm{~kg}$ $\mathrm{P} \mathrm{ha}{ }^{-1}+90 \mathrm{~kg} \mathrm{~N} \mathrm{ha}^{-1}$ for a wide range of soil qualities, indicating that there is room to improve current crop productivity through fertiliser use. To ensure their efficient use in sub-Saharan Africa mineral fertilisers should be: (1) targeted to specific niches of soil fertility within heterogeneous farms; and (2) go hand-in-hand with the implementation of agronomic measures to improve their capture and utilisation.

Keywords N use efficiency P P use efficiency .

K use efficiency - QUEFTS model ·

Soil fertility gradients · Sub-Saharan Africa

\section{Introduction}

Afrique-"Le développement ne se fera pas sans engrais" (Africa- "Development will not be achieved without fertilisers"- - Le Courrier International on April 14 2006, quoting an African political leader prior to the Africa Fertiliser Summit held in June 2006 in Abuja, Nigeria). There is increasing agreement among the research, development and donor communities on the need to facilitate farmers' access to mineral fertilisers to improve agricultural productivity in sub-Saharan Africa. Fertilizers are regarded to be essential to tackle land degradation and food insecurity in densely populated regions such as western Kenya, where small landholdings prevent the practice of fallow to replenish soil fertility, and lack of communal rangeland limits the inflow of nutrients through livestock into the farm system. Currently, crop production in the region is strongly limited by soil $\mathrm{N}$ and $\mathrm{P}$ availability and the gap between the actual and the attainable yield of maize, the major crop in the area, may be as wide as $5 \mathrm{t}$ grain ha ${ }^{-1}$ year $^{-1}$ (Rutunga et al. 2003). However, mineral fertilisers represent an important investment for farmers, particularly in remote areas with limited access to input markets - in Kenya transport costs often double the price of fertilisers in rural areas (IFDC 2003). From both economic and environmental viewpoints, mineral fertilisers should be targeted strategically within the cropping systems to ensure efficient nutrient recovery and conversion into crop biomass and yield.

The use of mineral fertilisers in much of subSaharan Africa has been promoted through 'blanket recommendations', i.e., recommendations based on regional soil surveying or on agroecological zoning that are specific for a given crop and area or soil type. (e.g. FURP 1994; Benson 1997). A major problem with this approach is the fact that in many areas smallholder farms are spatially heterogeneous in terms of soil quality, and thus the potential effect of applied nutrients varies dramatically from field to field (as well as from season to season). Evidence for this variability between fields has been presented for cereal and legume crops in East (Vanlauwe et al. 2006), West (Wopereis et al. 2006) and southern Africa (Zingore et al. 2007). These studies highlighted important differences in nutrient recoveries from applied fertilisers between the various fields of individual farms, stressing the need to consider this heterogeneity when deriving fertiliser recommendation domains. But can the observed gaps between current and attainable yields be explained solely by soil nutrient deficiencies or poor fertiliser recovery?

Farm heterogeneity results from the inherent variation in soil types on the landscape plus the effect of historical land use and management practices in different fields within the farm. Reinforcing this variability, farmers often prioritise resource and labour allocation to their best yielding fields; hence fields with better soils are planted earlier, weeded more frequently, and cultivated with improved seeds and nutrient inputs (Tittonell et al. 2007a). Biophysical and management factors, and their interactions at farm scale, affect both components of resource use efficiency-capture efficiency and conversion efficiency - thus contributing to the yield gap between maize yields obtained by smallholder farmers and yields attained under well-controlled conditions (e.g. in research plots). The factors that determine this yield gap also affect the response to fertilisers. Comparing farmer- and researcher-managed crops may give, therefore, a first indication of how management within smallholder farms influences yield gaps and what may be the room of manoeuvre to improve utilisation of nutrients.

The small amounts of mineral fertilisers that farmers can access should be targeted to niches of greatest crop responsiveness within heterogeneous 
farms. To contribute to this aim, our objectives were to analyse: (1) the impact of soil heterogeneity on the components of crop productivity and nutrient use efficiency that determine crop responses to $\mathrm{N}-\mathrm{P}-\mathrm{K}$ mineral fertiliser applications; and (2) the expected response of maize to mineral fertilisers on the basis of soil fertility indicators in smallholder farms of western Kenya. We focused on the major nutrient resources for crop production, N, P and $\mathrm{K}$ (water and other nutrients were not explicitly considered). The components of nutrient use efficiency analysed were thus: N, P and $\mathrm{K}$ availability, capture and conversion efficiency. We examined the range of variability in the values of these components within individual farms and across localities by re-analysing existing datasets from on-farm surveys and experiments in the region.

\section{Materials and methods}

System characterisation and analytical approach

The western Kenya region is one of the most densely populated areas of sub-Saharan Africa, due to large initial human settlements that were attracted by its high agroecological potential for crop production: a bimodal rainfall regime and relatively deep soils dominated by clay and loam textures, which were inherently fertile. Yet, there is ample sub-regional variability in rainfall/evapotranspiration regimes and soil-landscape types across western Kenya. The datasets that we used in this study included three sites in western Kenya: Aludeka division in Teso district $\left(0^{\circ} 35^{\prime} \mathrm{N} ; 34^{\circ} 19^{\prime} \mathrm{E}\right)$, Emuhaya division in Vihiga district $\left(0^{\circ} 4^{\prime} \mathrm{N} ; 34^{\circ} 38^{\prime} \mathrm{E}\right)$ and Shinyalu division in Kakamega district $\left(0^{\circ} 12^{\prime} \mathrm{N} ; 34^{\circ} 48^{\prime} \mathrm{E}\right)$. Gradients in altitude, rainfall, topography and soil types as well as differences in population density, ethnic groups, and access to markets and land use were observed between these sites, which encompass much of the variability found in the region (Table 1).

In conducting our analysis we followed the conceptualisation of Trenbath (1986): crop productivity results from the availability of biophysical resources such as light, water and nutrients, the ability of the crop to capture these resources and its capacity to convert them into biomass and grain yield, i.e.:Crop productivity $=$ resource availability $\times$ resource capture efficiency $\times$ resource conversion efficiency, where, resource capture efficiency represents the fraction of the total resource available that is intercepted/taken up by the crop, while the conversion efficiency represents biomass production per unit of resource taken up. For a given resource $\mathrm{R}$ the units are: $\left[\mathrm{kg}\right.$ dry matter $\left.\mathrm{ha}^{-1}\right]=\left[\mathrm{kg} \mathrm{R} \mathrm{ha}^{-1}\right] \times$ $\left[\mathrm{kg} \mathrm{R}_{\text {taken-up }} \mathrm{kg}^{-1} \mathrm{R}_{\text {available }}\right] \times\left[\mathrm{kg}\right.$ dry matter $\left.\mathrm{kg}^{-1} \mathrm{R}_{\text {taken-up }}\right]$. In the model of Trenbath (1986) the partitioning of the total crop biomass towards harvestable crop parts may be considered as an intrinsic component of the

Table 1 Key characteristics for the three sites selected to represent the socio-economic and biophysical variability of western Kenya

\begin{tabular}{|c|c|c|c|}
\hline & \multicolumn{3}{|l|}{ Locality } \\
\hline & Aludeka & Emuhaya & Shinyalu \\
\hline $\begin{array}{l}\text { Agroecological } \\
\text { zone }^{\mathrm{a}}\end{array}$ & $\begin{array}{l}\text { LM2: lower midland sugar } \\
\text { cane zone; altitude: } 1180 \mathrm{~m} \text {; } \\
\text { mean annual temperature: } \\
22.2^{\circ} \mathrm{C} \text {; annual rainfall: } \\
1,460 \mathrm{~mm} \text { (bimodal) }\end{array}$ & $\begin{array}{l}\text { UM1: upper midland tea-coffee } \\
\text { zone; altitude: } 1640 \mathrm{~m} \text {; mean } \\
\text { annual temperature: } 20.4^{\circ} \mathrm{C} \text {; } \\
\text { annual rainfall: } 1,850 \mathrm{~mm} \\
\text { (bimodal) }\end{array}$ & $\begin{array}{l}\text { UM1: upper midland tea-coffee } \\
\text { zone; altitude: } 1820 \mathrm{~m} \text {; mean } \\
\text { annual temperature: } 20.8^{\circ} \mathrm{C} \text {; annual } \\
\text { rainfall: } 2,150 \mathrm{~mm} \text { (bimodal) }\end{array}$ \\
\hline $\begin{array}{l}\text { Topography } \\
\text { and soil types }\end{array}$ & $\begin{array}{l}\text { Slopes } 2-5 \% \text {; Acrisols } \\
\text { (petroferric phase), Luvisols, } \\
\text { Lixisols, Vertisols }\end{array}$ & $\begin{array}{l}\text { Slopes } 2-15 \% \text {; nito-humic } \\
\text { Ferralsols and dystro-mollic } \\
\text { Nitosols (acidic phase) }\end{array}$ & $\begin{array}{l}\text { Slopes up to } 45 \% \text {; humic Nitosols } \\
\text { and dystro-mollic Nitosols } \\
\text { (acidic phase) }\end{array}$ \\
\hline $\begin{array}{l}\text { Socioeconomic } \\
\text { and land use } \\
\text { aspects }\end{array}$ & $\begin{array}{l}\text { Relatively sparsely populated } \\
\left(310 \text { inh. } \mathrm{km}^{-2} \text { ); limited access }\right. \\
\text { to urban markets, marginal } \\
\text { rural markets; main crops: } \\
\text { maize, cassava, sorghum } \\
\text { and finger millet }\end{array}$ & 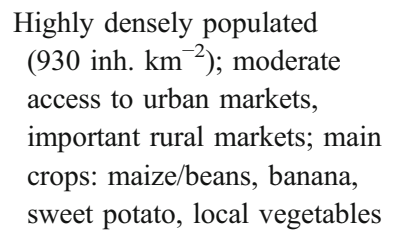 & $\begin{array}{l}\text { Densely populated ( } 650 \text { inh. } \mathrm{km}^{-2} \text { ); } \\
\text { limited access to urban markets, } \\
\text { important rural markets; main } \\
\text { crops: maize/beans, fruit trees, } \\
\text { sweet potato, local vegetables }\end{array}$ \\
\hline
\end{tabular}

\footnotetext{
${ }^{a}$ According to the agroecological zoning of Kenya by Jaetzold and Schmidt (1982)
} 
conversion efficiency. Here, we considered the Harvest index as a separate component of crop productivity (expressed in grain yield units).

We examined the variability in each of the above crop productivity components across heterogeneous farms as affected, individually or simultaneously, by soil properties and agronomic management. This was done by focusing on nutrient resources and reanalysing two existing datasets: (1) one comprising maize yields, management variables and soil properties from farmer-managed (F-M) fields on 60 farms across the three sites mentioned above (Tittonell et al. 2005b); and (2) another one consisting of data from on-farm researcher-managed (R-M) experiments which were conducted to evaluate maize responses to $\mathrm{N}-\mathrm{P}-\mathrm{K}$ fertiliser applications in the same localities (and farms; Vanlauwe et al. 2006). We then used the model 'Quantitative Evaluation of the Fertility of Tropical Soils' (QUEFTS_Janssen et al. 1990) to predict crop yields from information on actual soil fertility and recovery fractions of applied nutrients.

\section{Datasets}

\section{Soil fertility and maize yields under farmer management ( $F-M)$}

This dataset consists of maize yields measured on farmers' fields with no intervention from researchers. We selected 20 case-study farms per locality (Table 1 ), encompassing the socio-economic diversity of households, from a farm survey conducted during the long rains season of 2002. We walked through each farm along a transect together with the farmer and discussed each field in turn, aided by a map of the farm drawn by him/her. On the various maize fields identified on each farm we recorded the cultivar(s) used, the type and amount of inputs applied, the timing and sequential order of crop and soil management activities, the average yields obtained, weed infestation, and general crop husbandry practices (e.g. plant density). Maize yields were estimated on each field by non-destructive plant morphological measurements, using allometric models described by Tittonell et al. (2005a). Topsoil (0-15 and 0-30 cm) samples were taken from each maize field and geo-referenced; samples were air-dried, sieved through $2 \mathrm{~mm}$, stored at room temperature, and analysed for particle size distribution, organic $\mathrm{C}$, total $\mathrm{N}$, extractable $\mathrm{P}$ (Olsen), exchangeable $\mathrm{K}^{+}, \mathrm{Ca}^{2+}, \mathrm{Mg}^{2+}$ and $\mathrm{H}^{+}$using standard methods for tropical soils (Anderson and Ingram 1993). In total 159 observation points were generated containing F-M maize yields, management factors and soil fertility data (Tittonell et al. 2007b). They are referred to as the farmer-managed (F-M) plots.

\section{On-farm maize response to fertilisers under researcher management $(R-M)$}

This dataset consists of maize yields from experimental plots laid on a sub-sample of the farmers' fields that had been surveyed in the previous rainy season, and managed by researchers (R-M plots). At each locality, six farms were chosen out of the 60 farms previously surveyed to include farmers from different social status (two with respectively high, medium, and low access to resources) and gender. In each farm, three fields were chosen at different distances to the homestead (homefields, midfields, outfields), based on the analysis of resource allocation patterns and on farmers' opinions on the soil fertility status of the different fields. In each of the fields, five treatments were laid out on plots of $4.5 \times 2.25 \mathrm{~m}$, following a one-farm, one-replicate design: a no-input control, a fully fertilized treatment $\left(100 \mathrm{~kg} \mathrm{~N} \mathrm{ha}^{-1}\right.$, $100 \mathrm{~kg} \mathrm{P} \mathrm{ha}{ }^{-1}$, and $100 \mathrm{~kg} \mathrm{~K} \mathrm{ha}{ }^{-1}$ ), and three treatments with one of the major nutrients $(\mathrm{N}, \mathrm{P}$, or $\mathrm{K})$ missing. The experiment was conducted during the short rains of 2002; a hybrid maize cultivar HB513 (medium-duration type) was grown, receiving fertiliser as urea, triple super phosphate, and muriate of potash. One third of the $\mathrm{N}$ fertilizer and the $\mathrm{P}$ and $\mathrm{K}$ fertilizers were applied broadcast on the entire plot and incorporated before planting. The plots were hoeweeded three times during the growing season. At the 5th week after planting, two thirds of the $\mathrm{N}$ fertilizer was top dressed by banding urea in the rows of maize. Topsoil $(0-15 \mathrm{~cm})$ samples were taken with an auger at eight sampling points (4 on each diagonal) per field from the three fields chosen within each farm, and analysed following standard methods (Anderson and Ingram 1993). A summary of the soil characteristics across locations and field types is presented in Table 2. Maize was harvested about 15 weeks after planting; fresh and dry weights of and N, P and $\mathrm{K}$ contents in different plant parts were determined. Further details on this dataset were reported by Vanlauwe et al. (2006). 
Table 2 Average soil properties and their range of variation measured on the experimental plots laid out on farmers' fields (R-M plots)

\begin{tabular}{|c|c|c|c|c|c|c|c|c|}
\hline \multirow{2}{*}{$\begin{array}{l}\text { Locality/position } \\
\text { within the farms } \\
\text { Aludeka }\end{array}$} & \multicolumn{2}{|c|}{$\begin{array}{l}\text { Soil organic } \\
\mathrm{C}\left(\mathrm{g} \mathrm{kg}^{-1}\right)\end{array}$} & \multicolumn{2}{|c|}{$\begin{array}{l}\text { Total soil } \mathrm{N} \\
\left(\mathrm{g} \mathrm{kg}^{-1}\right)\end{array}$} & \multicolumn{2}{|c|}{$\begin{array}{l}\text { Extractable } \\
\mathrm{P}\left(\mathrm{mg} \mathrm{kg}^{-1}\right)\end{array}$} & \multicolumn{2}{|c|}{$\begin{array}{l}\text { Exchangeable } \\
\mathrm{K}\left(\mathrm{cmol}_{(+)} \mathrm{kg}^{-1}\right)\end{array}$} \\
\hline & & & & & & & & \\
\hline Homefields & 10.9 & $(9.6-12.2)$ & 0.9 & $(0.6-1.4)$ & 12.0 & $(1.9-26.3)$ & 0.79 & $(0.16-1.76)$ \\
\hline Midfields & 6.6 & $(5.8-7.6)$ & 0.6 & $(0.5-0.7)$ & 3.2 & $(1.2-6.0)$ & 0.32 & $(0.12-0.47)$ \\
\hline Outfields & 6.7 & $(4.5-7.6)$ & 0.6 & $(0.4-0.8)$ & 2.8 & $(1.3-6.8)$ & 0.30 & $(0.13-0.75)$ \\
\hline \multicolumn{9}{|l|}{ Emuhaya } \\
\hline Homefields & 17.4 & $(12.2-25.5)$ & 1.3 & $(0.9-1.6)$ & 11.1 & $(2.8-29.4)$ & 0.60 & $(0.15-1.96)$ \\
\hline Midfields & 12.8 & $(8.9-16.4)$ & 1.2 & $(0.8-1.5)$ & 4.8 & $(2.1-8.9)$ & 0.62 & $(0.07-2.16)$ \\
\hline Outfields & 11.7 & $(7.5-15.1)$ & 1.1 & $(0.9-1.4)$ & 1.7 & $(0.6-2.2)$ & 0.22 & $(0.06-0.59)$ \\
\hline \multicolumn{9}{|l|}{ Shinyalu } \\
\hline Homefields & 19.6 & $(16.9-24.0)$ & 1.7 & $(1.5-1.9)$ & 10.0 & $(2.6-26.4)$ & 0.41 & $(0.18-0.63)$ \\
\hline Midfields & 17.2 & $(13.6-21.0)$ & 1.6 & $(1.2-1.9)$ & 3.8 & $(1.9-7.3)$ & 0.47 & $(0.08-1.05)$ \\
\hline Outfields & 16.2 & $(13.5-18.4)$ & 1.5 & $(1.2-1.7)$ & 2.5 & $(1.6-4.3)$ & 0.24 & $(0.10-0.46)$ \\
\hline
\end{tabular}

The model QUEFTS

QUEFTS is a simple and robust tool, relatively undemanding of data, that has been applied to the evaluation of fertiliser requirements in the tropics (e.g. Witt et al. 1999; Pathak et al. 2003). QUEFTS has been calibrated to estimate fertiliser requirements and grain yield of tropical maize in Kenya (Smaling and Janssen 1993). Predicted yields using QUEFTS are an indication of attainable yields given the nutrient availability from soil and fertilisers; i.e., the effect of water availability or other 'management' factors are not considered. We used QUEFTS to analyse: (1) the variability in nutrient use efficiency caused by factors other than nutrient availability by calculating the extent to which QUEFTS-predicted maize yields deviated from those measured on-farm; and (2) the variability in crop responses to fertilisers that is caused exclusively by the availability of nutrients in the soil and their interactions across heterogeneous farms.

\section{Overview}

The model assumes that crop yield is a function of $\mathrm{N}$, $\mathrm{P}$ and $\mathrm{K}$ availabilities (native soil supply + mineral fertiliser added) and their interaction. The model estimates grain yield through four calculation steps:

1. Quantification of the potential native soil supply of $\mathrm{N}(\mathrm{SN}), \mathrm{P}(\mathrm{SP})$ and $\mathrm{K}(\mathrm{SK})$ using soil chemical data or from crop nutrient uptake measured in nutrient-omission trials;

2. Estimation of the actual crop nutrient uptake (UN, UP and UK, respectively) as a function of the native soil supply of a nutrient plus the supply from chemical fertiliser taking a fertiliser recovery fraction into account;

3. Estimation of N-, P- and K-determined yield ranges as a function of calculated nutrient uptake and a cultivar-specific potential yield $\left(Y_{\max }\right)$, considering minimum and maximum internal $\mathrm{N}$, $\mathrm{P}$ and $\mathrm{K}$ use efficiencies (i.e. the inverse of the crop-specific maximum and minimum $\mathrm{N}, \mathrm{P}$ and $\mathrm{K}$ concentrations, respectively), leading to, respectively, minimum and maximum $\mathrm{N}, \mathrm{P}$ and $\mathrm{K}$ determined yields (YNA: yield at maximum $\mathrm{N}$ accumulation, YND: yield at maximum $\mathrm{N}$ dilution, etc.);

4. Estimation of the final yield by accounting for the interactions between $\mathrm{N}, \mathrm{P}$ and $\mathrm{K}$, i.e. as the average of yield estimates that are calculated for each possible pair of nutrients.

These four steps are described in detail in Janssen et al. (1990). Here, we only present the equations for calculation of the potential soil supply of N, P and K, as they are explicitly referred to in some of our analyses:

$\mathrm{SN}=f \mathrm{~N} \times 6.8 \times$ soil organic $\mathrm{C}$ 


$$
\begin{aligned}
\mathrm{SP}= & f \mathrm{P} \times 0.35 \times \text { soil organic } \mathrm{C}+0.5 \\
& \times \text { extractable }(\text { Olsen }) \mathrm{P} \\
\mathrm{SK}= & (f \mathrm{~K} \times 400 \times \text { exchangeable } \mathrm{K}) / \\
& (2+0.9 \times \text { Soil organic } \mathrm{C})
\end{aligned}
$$

Where, soil organic $\mathrm{C}$ is expressed in $\mathrm{g} \mathrm{C} \mathrm{kg}^{-1}$ soil, extractable $\mathrm{P}$ in $\mathrm{mg} \mathrm{P}^{-1}$ soil, exchangeable $\mathrm{K}$ in $\mathrm{cmol}_{(+)} \mathrm{kg}^{-1}$ soil, and $f \mathrm{~N}, f \mathrm{P}$ and $f \mathrm{~K}$ are correction factors due to soil $\mathrm{pH}$, calculated as:

$$
\begin{aligned}
& f \mathrm{~N}=0.25 \times(\mathrm{pH}-3) \\
& f \mathrm{P}=1-0.5 \times(\mathrm{pH}-6)^{2} \\
& f \mathrm{~K}=0.625 \times(3.4-0.4 \times \mathrm{pH})
\end{aligned}
$$

\section{Model parameterisation and simulations}

First, we performed yield calculations with QUEFTS using the standard parameterisation from Smaling and Janssen (1993) for maize in Kenya, and soil characteristics from the survey of the F-M maize fields. The default values for the recovery fraction of applied $\mathrm{N}$, $\mathrm{P}$ and $\mathrm{K}$ were $0.5,0.1$ and 0.5 , respectively. Based also on the original parameterisation, the yield potential $Y_{\max }$ was set at $10 \mathrm{t}$ grain $\mathrm{ha}^{-1}$, which is a reasonable value for the short rains in the highlands of Kenya (from the examination of the results of the R-M trials there was not enough evidence to assume a different $Y_{\max }$ across the three sites of the study). The sensitivity of QUEFTS yield predictions to values of $Y_{\max }$ ranging from 6 to $14 \mathrm{t} \mathrm{ha}^{-1}$ was analysed for $\mathrm{N}-\mathrm{P}-\mathrm{K}$ application regimes ranging from control (no fertilisers) to $300: 300: 300 \mathrm{~kg} \mathrm{ha}^{-1}$ and using the default recovery rates. The relative partial sensitivity (RPS) was calculated as the ratio between the relative change in QUEFTS-predicted yield and the relative change in $Y_{\max }$.

Maize yields predicted by QUEFTS were compared with yields measured in F-M fields. Only the farmers' maize fields cultivated without nutrient inputs (no chemical fertilizer, no manure application) were considered. F-M fields receiving nutrient inputs were not used for model testing due to the poor reliability in the estimates of such inputs. Farmers do not always recall accurately the amounts of fertiliser they applied to their crops in the previous season. We then assessed the model's sensitivity to nutrient inputs (on F-M fields) by running it for a series of scenarios of combined N, P and/or K applications, each element at a rate of $100 \mathrm{~kg} \mathrm{ha}^{-1}$. Secondly, we calibrated QUEFTS using data from the R-M experimental plots by tuning capture efficiencies of applied nutrients within the range of recovery efficiencies calculated from the experimental data to minimise differences between model predictions and measured yields. With this new parameterisation QUEFTS was used to assess maize yield responses to application of $\mathrm{P}$ fertiliser (as $\mathrm{P}$ was observed to be the main limiting nutrient-see later) at a rate of $30 \mathrm{~kg} \mathrm{P} \mathrm{ha}^{-1}$ (30P) alone or in the presence of $\mathrm{N}$ fertiliser, applied at a rate of $90 \mathrm{~kg} \mathrm{~N} \mathrm{ha}^{-1}(30 \mathrm{P} / 90 \mathrm{~N})$ - the maximum rate for an economic response estimated in previous studies (FURP 1994), and above the general minimum recommendation of $60 \mathrm{~kg} \mathrm{~N} \mathrm{ha}^{-1}$.

Data analysis and calculations

The yields from the on-farm experiments (R-M) were analysed through simple calculations of relative yield responses to fertilisers, nutrient capture and conversion efficiencies.

Relative yield responses to fertiliser applications were calculated as follows:

Relative response to treatment $\mathrm{X}=$

$$
\begin{aligned}
& {\left[\operatorname{grain} \operatorname{yield}_{(\text {treatment X) }}-\operatorname{grain}_{\text {yield }}(\text { control) })\right] /} \\
& \operatorname{grain~yield}_{(\text {control })} \text {, }
\end{aligned}
$$

where, treatment $\mathrm{X}$ represents $\mathrm{N}-\mathrm{P}, \mathrm{N}-\mathrm{K}, \mathrm{P}-\mathrm{K}$ or $\mathrm{N}-$ $\mathrm{P}-\mathrm{K}$ fertiliser application.

The apparent nutrient recovery (a proxy for nutrient capture efficiency) from fertilisers was calculated by comparing nutrient uptake between treatment and control. For instance, the apparent recovery of $\mathrm{N}$ in $\mathrm{N}-\mathrm{P}-\mathrm{K}$ treatments is calculated as:

Apparent $\mathrm{N}$ recovery $=$

$$
\left[\mathrm{N} \text { uptake }_{(\mathrm{NPK})}-\mathrm{N} \text { uptake }_{(\text {control })}\right] / \text { applied } \mathrm{N},
$$

where the rate of applied $\mathrm{N}$, as well as $\mathrm{P}$ and $\mathrm{K}$ was $100 \mathrm{~kg} \mathrm{ha}^{-1}$ for all treatments receiving nutrients. 
The efficiency of conversion of nutrients taken up by the plant into crop biomass was calculated as follows:

Conversion efficiency of nutrient $\mathrm{X}=$

total aboveground biomass/

total uptake of nutrient $\mathrm{X}$,

where, the total aboveground biomass is the sum of grain plus stover biomass, expressed on a dry weight basis. The conversion efficiencies for $\mathrm{N}, \mathrm{P}$ and $\mathrm{K}$

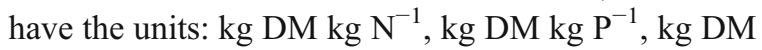
$\mathrm{kg} \mathrm{K}^{-1}$ taken up by the crop, respectively. The uptake of nutrients was calculated from measurements of $\mathrm{N}$, $\mathrm{P}$ and $\mathrm{K}$ contents in grain and stover biomass (roots were not considered).

Regression analysis and analysis of variance (ANOVA) were performed using Genstat 8. To evaluate the accuracy of the QUEFTS model predictions, regression analysis was performed between the predicted and the measured yields and the total difference was calculated as the root mean square error, RMSE.

\section{Results}

Magnitude of yield gaps

Maize yields under farmer management (F-M) differed significantly across localities $(P=0.002)$, with averages of $1.1,2.0$ and $1.9 \mathrm{t} \mathrm{ha}^{-1}$ for Aludeka, Emuhaya and Shinyalu, respectively. At each locality the average yields under F-M were significantly larger $(P<0.001)$ in fields receiving organic and/or mineral nutrient inputs (the average standard error of the differences was $0.23 \mathrm{t} \mathrm{ha}^{-1}$ ), irrespective of their application rate, and there was no significant interaction between input use and locality (Fig. 1a). The average yields under F-M also decreased significantly from the home- to the outfields $(P<0.001)$ in all localities (the interaction locality $\mathrm{x}$ position within farm was not significant; Table 3). Yields on the same field plots but under researcher management (R-M) were larger than under F-M, both for the control (without fertilizer) and the fully fertilised treatments. Yields under R-M did not vary significantly across localities ( $P=0.058)$ on the control subplots; however, they differed significantly $(P<0.001)$ when full rates of mineral $\mathrm{N}-\mathrm{P}-\mathrm{K}$ fertilisers were applied, with averages of $4.3,4.0$ and $2.8 \mathrm{t} \mathrm{ha}^{-1}$ for Aludeka, Emuhaya and Shinyalu, respectively. Conversely, while yields on R-M control plots within each locality decreased with the distance from the homestead $(P<0.01)$, they did not differ significantly when $\mathrm{N}-\mathrm{P}-\mathrm{K}$ fertilisers were applied at full rate. At this scale of analysis, these results suggest that: (1) improved crop management under R-M contributed to reduce the gap between potential and actual yields even when fertilisers were not applied (control plots), reducing differences across localities; and that (2) N$\mathrm{P}-\mathrm{K}$ fertiliser applications at full rate (100:100:100 kg element $\mathrm{ha}^{-1}$ ) contributed to erase or minimise yield differences between different fields of the farm.

Maize yields under F-M were larger in Emuhaya and Shinyalu than in Aludeka, while yields in Aludeka were larger than for the other localities under R-M, especially when fertilisers were applied. The gap between the average yields under F-M (irrespective of nutrient input
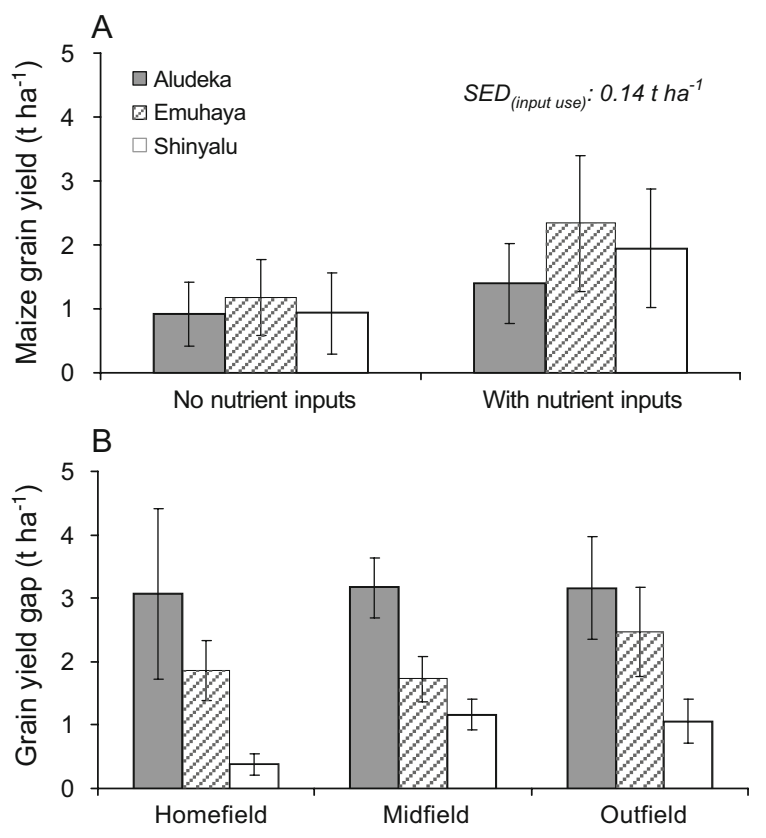

Fig. 1 a Average maize grain yield under farmers' management $(\mathrm{F}-\mathrm{M})$ without and with nutrient inputs in the long rains season of 2002 (Feb-July) across three localities of western Kenya. b The gap between maize yields under F-M and yields obtained with application of $\mathrm{N}-\mathrm{P}-\mathrm{K}$ fertilisers on the same fields under researcher management (R-M) in the following season (short rains of 2002, Sept-Dec) 
Table 3 Average and range of variation of maize grain yields ( $\left.\mathrm{tha}^{-1}\right)$ under farmers' management (F-M) in the long-rains 2002, average yields and yield ranges for control and $\mathrm{N}-\mathrm{P}-\mathrm{K}$ treatments from the researcher-managed (R-M) on-farm experiments in the short rains 2002, and reference yields under controlled, on-station trials (FURP 1994)

\begin{tabular}{|c|c|c|c|c|c|c|c|c|}
\hline \multirow[t]{2}{*}{$\begin{array}{l}\text { Locality/position } \\
\text { within the farms }\end{array}$} & \multicolumn{2}{|c|}{$\begin{array}{l}\text { Farmers' fields }{ }^{\mathrm{a}} \\
\text { (farmer management) }\end{array}$} & \multicolumn{2}{|c|}{$\begin{array}{l}\text { Control plots } \\
\text { (on-farm experiment) }\end{array}$} & \multicolumn{2}{|c|}{$\begin{array}{l}\text { Full N-P-K plots } \\
\text { (on-farm experiment) }\end{array}$} & \multicolumn{2}{|c|}{$\begin{array}{l}\text { FURP-reference }{ }^{b} \\
\text { (on-station experiment) }\end{array}$} \\
\hline & & & & & & & Control & Fertilised $^{\mathrm{c}}$ \\
\hline \multicolumn{9}{|l|}{ Aludeka } \\
\hline Homefields & 1.7 & $(1.2-2.3)$ & 3.6 & $(2.1-7.3)$ & 4.7 & $(2.5-7.4)$ & & \\
\hline Midfields & 1.0 & $(0.8-1.3)$ & 2.0 & $(1.0-2.8)$ & 4.1 & $(3.2-5.0)$ & 1.6 & 5.2 \\
\hline Outfields & 0.7 & $(0.3-1.1)$ & 1.8 & $(1.1-2.4)$ & 3.9 & $(2.1-5.0)$ & & \\
\hline \multicolumn{9}{|l|}{ Emuhaya } \\
\hline Homefields & 2.4 & $(1.1-3.8)$ & 2.9 & $(0.9-5.5)$ & 4.2 & $(3.3-6.2)$ & & \\
\hline Midfields & 2.2 & $(0.9-3.6)$ & 2.6 & $(1.2-3.7)$ & 4.0 & $(2.9-4.8)$ & 2.3 & 6.0 \\
\hline Outfields & 1.4 & $(0.7-2.9)$ & 1.8 & $(0.3-3.0)$ & 3.8 & $(2.7-5.5)$ & & \\
\hline \multicolumn{9}{|l|}{ Shinyalu } \\
\hline Homefields & 2.6 & $(1.7-4.0)$ & 2.3 & $(1.3-3.3)$ & 2.9 & $(1.4-5.4)$ & & \\
\hline Midfields & 1.7 & $(0.7-2.1)$ & 1.6 & $(1.1-1.9)$ & 2.8 & $(2.0-3.5)$ & 2.3 & 7.1 \\
\hline Outfields & 1.4 & $(0.8-2.3)$ & 1.0 & $(0.2-2.3)$ & 2.5 & $(1.2-3.7)$ & & \\
\hline SED & 0.26 & & 0.39 & & 0.38 & & & \\
\hline $\mathrm{CV}$ & 0.46 & & 0.54 & & 0.31 & & & \\
\hline
\end{tabular}

$S E D$ standard error of the differences, $C V$ coefficient of variation (=standard deviation/grand mean across sites and fields), FURP Fertiliser Use and Recommendation Programme, Kenya National Agricultural Research Laboratory

${ }^{a}$ These include fields managed by farmers with and without nutrient inputs (fertilizers, manure, organic wastes) at variable rates.

${ }^{\mathrm{b}}$ The position within the farm does not hold in this case

${ }^{\mathrm{c}}$ The figures correspond to fertilizer combinations and rates leading to the highest yields (excluding those that also received animal manure) at each site. Maize grown during the long rains season.

use) and the yields under R-M with full $\mathrm{N}-\mathrm{P}-\mathrm{K}$ was as wide as $3 \mathrm{t} \mathrm{ha}^{-1}$ across all field types in Aludeka (Fig. 1b), while it was narrower and tended to increase with distance from the homestead in Emuhaya and Shinyalu. Shinyalu is a higher and somewhat cooler locality (cf. Table 1), where the short rains season is considered marginal for maize production and many farmers leave the fields as short fallow, use them for grazing or plant short cycle crops such as beans (Tittonell et al. 2005b). In Aludeka, maize is a relatively new crop that increasingly is replacing other staple food crops such as sorghum or cassava; yields were virtually doubled simply by the effect of improved agronomic management in this locality, as evidenced by the yield gap between average yields under F-M and yields in non-fertilised control plots under R-M (Table 3). The yield gaps between the average yields under F-M and reference maize yields of fully fertilised crops from onstation trials (FURP, 1994-Table 3) were even larger (on average 4.1, 4.0 and 5.2 $\mathrm{tha}^{-1}$ in Aludeka, Emuhaya and Shinyalu, respectively), indicating a large potential for improving actual crop productivity.
Management-induced heterogeneity and its effect on crop responses

Crop production on the same field plots under F-M (with and without nutrient inputs) or under R-M without fertilisers tended to increase with increasing soil organic $\mathrm{C}\left(r^{2}=0.21\right.$ and $r^{2}=0.10$, respectively; $P<0.01)$ but not on plots receiving full NPK under R-M $\left(r^{2}=0.02 ; P<0.01\right.$; Fig. 2 a). Soil organic $C$ is used as a proxy for soil fertility. While native soil $\mathrm{N}$ availability is normally positively correlated with soil organic $\mathrm{C}$ due to the largest proportion of $\mathrm{N}$ being in an organic form in the soil, $\mathrm{P}$ availability (i.e. Olsen-extractable P) may also be related to soil $\mathrm{C}$ but through the management history of the fields. In smallholder farms in the region fields closer to the homesteads receive $\mathrm{P}$ inputs (through e.g. ash, animal manure or sporadic fertiliser use) together with $\mathrm{C}$ inputs (e.g., manure, household waste). This also leads to larger biomass yields and, thus, larger $\mathrm{C}$ inputs to the soil if crop residues are not removed after harvest. Due to such management-induced co- 


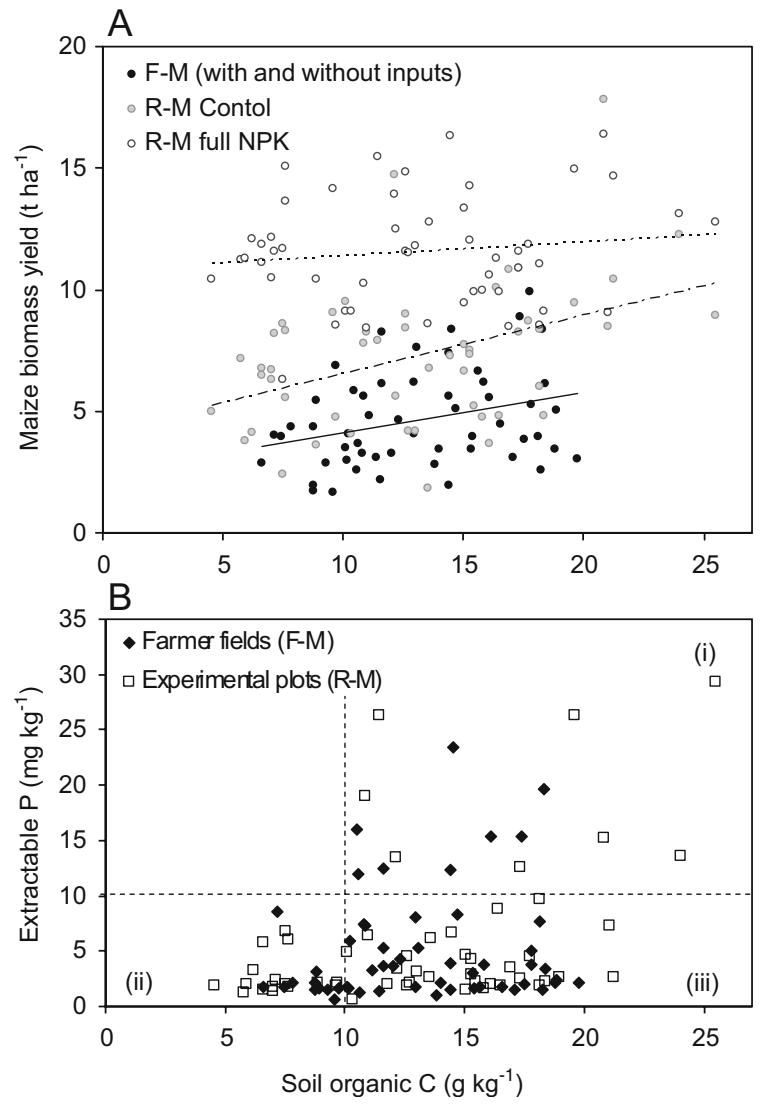

Fig. 2 a Maize grain yields under farmers' management (F-M) with or without nutrient inputs, and under researchers' management (R-M) without fertilisers (control) and with $\mathrm{N}-$ $\mathrm{P}-\mathrm{K}$ fertilisers $\left(100: 100: 100 \mathrm{~kg} \mathrm{ha}^{-1}\right)$ plotted against soil organic C. b Measured soil extractable (Olsen) P plotted against measured soil organic $\mathrm{C}$ in all F-M and R-M fields prior to the experiment

variation, soils with less than $10 \mathrm{~g} \mathrm{~kg}^{-1}$ of organic $\mathrm{C}$ had extractable $\mathrm{P}$ values below the indicated threshold of $10 \mathrm{mg} \mathrm{kg}^{-1}$ - [quadrant (2) in Fig. 2b], whereas soils with larger organic $\mathrm{C}$ content might have high [quadrant (1)] or low [quadrant (3)] availability of $\mathrm{P}$. Such a positive relationship between soil $\mathrm{C}$ and $\mathrm{P}$ availability was also observed for a set of c. 600 samples from western Kenya (Tittonell et al. 2007b). When mineral $\mathrm{P}$ fertilisers are applied alone, fields in quadrant (1) are expected to respond weakly due to relatively good availability of $\mathrm{P}$, fields in quadrant (2) may show little response to $\mathrm{P}$ if mineral $\mathrm{N}$ fertilisers or manure are not simultaneously applied, while fields in quadrant (3) are expected to show the strongest response to sole $\mathrm{P}$ applications.
In R-M plots, the relative grain yield response to full N-P-K fertiliser applications (Eq. 7) tended to decrease for soils with higher organic $\mathrm{C}$ and extractable $\mathrm{P}$ contents in all localities (Figs. $3 \mathrm{a}$ and b). Such a pattern was mostly explained by the application of $\mathrm{N}$ and $\mathrm{P}$, as the relative yield increase induced by combined N-P applications showed similar trends as for $\mathrm{N}-\mathrm{P}-\mathrm{K}$ (Figs. $3 \mathrm{c}$ and $\mathrm{d}$ ). When either $\mathrm{P}$ (combined $\mathrm{N}-\mathrm{K}$ application) or $\mathrm{N}$ (combined $\mathrm{P}-\mathrm{K}$ application) was removed, somewhat larger responses were observed for soils of intermediate fertility in terms of $\mathrm{C}$ and $\mathrm{P}$ within each site (not shown). Yield increases with $\mathrm{N}-\mathrm{P}-\mathrm{K}$ were slightly larger than with $\mathrm{N}-\mathrm{P}$ only in Emuhaya, indicating some degree of yield limitation by $\mathrm{K}$ availability in those soils. Substantial yield responses to any of the nutrient combinations in the applied fertiliser were only observed across localities in soils with extractable (Olsen) P less than c. $10 \mathrm{mg} \mathrm{kg}^{-1}$ - a trend that has been previously observed across 18 sites in Kenya (Schnier et al. 1997). However, yield responses to $\mathrm{N}-\mathrm{P}-\mathrm{K}$ and $\mathrm{N}-\mathrm{P}$ in these fields were also often negligible (Figs. $3 \mathrm{~b}$ and d). Such variability in the response to fertilisers is related to the efficiency with which the crop captures the available nutrients and converts them into biomass. In the following section, we examine the range of variability of the components of resource use efficiency underlying variability in crop yields and their response to fertilisers.

Nutrient availability and utilisation across heterogeneous farms

Following the logic outlined in "System characterisation and analytical approach," nutrient-limited crop yields are the result of nutrient availability, nutrient capture efficiency and nutrient conversion efficiency. In the following paragraphs we examine the variability in soil N-P-K availabilities (i.e., prior to fertiliser addition), apparent $\mathrm{N}-\mathrm{P}-\mathrm{K}$ recovery efficiencies (proxies to $\mathrm{N}-\mathrm{P}-\mathrm{K}$ capture efficiencies from applied fertilisers) and N-P-K conversion efficiencies (the inverse of their concentration in crop biomass) within the farms sampled across the three localities.

\section{Soil nutrient availability}

The potential soil supply of N, P and $\mathrm{K}$ was estimated for all R-M fields using Equations 1, 2 and $3(S N, S P$ 
Fig. 3 Relative yield responses (yield increase relative to control plots) to combined N-P-K and N-P mineral fertiliser applications at rates of $(100 \mathrm{~kg} \mathrm{~N}$ $\mathrm{ha}^{-1}, 100 \mathrm{~kg} \mathrm{P} \mathrm{ha}^{-1}$ and $100 \mathrm{~kg} \mathrm{~K} \mathrm{ha}^{-1}$ ) in a nutrientomission trial conducted on 18 farms from Aludeka, Emuhaya and Shinyalu divisions in western Kenya (i.e., the on-farm R-M experiment). Relative responses plotted against soil organic carbon $(\mathbf{a}, \mathbf{c})$ and soil extractable $\mathrm{P}(\mathbf{b}, \mathbf{d})$
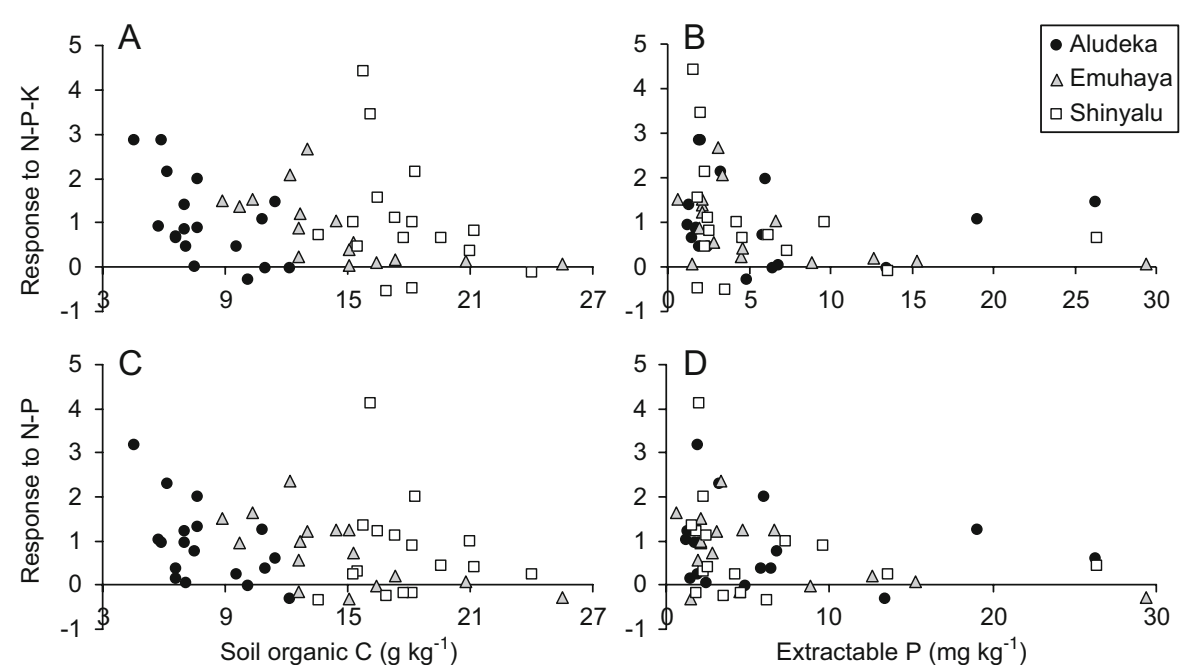

and $\mathrm{SK}$, respectively) and plotted against $\mathrm{N}, \mathrm{P}$ and $\mathrm{K}$ uptake in grain as measured in the control and in the PK, NK and NP plots, respectively (Figs. 4a, c and e). $S \mathrm{~N}, S \mathrm{P}$ and $S \mathrm{~K}$ were also plotted against measured soil properties in Figs. $4 \mathrm{~b}, \mathrm{~d}$ and $\mathrm{f}$ together with the measured uptakes of $\mathrm{N}, \mathrm{P}$ and $\mathrm{K}$ in grain and in total aboveground biomass (grain + stover) in the PK, NK and NP plots, respectively. $S \mathrm{~N}$ was in most cases larger than the measured uptake of $\mathrm{N}$ in grain (Fig. 4a), which would suggest either an incomplete uptake of soil available $\mathrm{N}$ or that a large part of the $\mathrm{N}$ taken up remained in the stover. $S \mathrm{~N}$ was closer to the uptake of $\mathrm{N}$ in grain on $\mathrm{PK}$ plots (grey circles) at the lower end of the range of total soil $\mathrm{N}$, but closer to the actual uptake of $\mathrm{N}$ in total aboveground biomass (crosses) at higher soil $\mathrm{N}$ values (Fig. 4b). The uptake of $\mathrm{P}$ and $\mathrm{K}$ on the control and on the NK and NP plots, respectively, was generally greater than the estimated soil supply of these nutrients, and much lower than the uptake of $\mathrm{P}$ and $\mathrm{K}$ in total aboveground biomass (Figs. 4c-e). Earlier work using these equations to calculate of soil N, P and K supply suggested also that the actual uptake measured on zero-input plots, or even grain yields on those plots (assuming average nutrient concentrations in grain) could be better used to estimate indigenous soil nutrient supply (Dobermann et al. 2003).

The actual uptake of N, P and K measured in total aboveground biomass decreased significantly from the home- to the outfields (Table 4), following the trends in maize yields on the control plots (cf. Table 3), and the average soil nutrient concentrations of the different fields (cf. Table 2). For the average maize grain yield in western Kenya of $1.1 \mathrm{t} \mathrm{ha}^{-1}$ (e.g. Hassan 1998) and average harvest index of 0.36 (as measured in the F-M fields), total aboveground biomass production corresponds to about $3 \mathrm{tha}^{-1}$ $(1.1 / 0.36=3)$. Assuming N, P and $\mathrm{K}$ conversion efficiencies (under balanced nutrient uptake) of 88 , 319 and $97 \mathrm{~kg}$ of dry matter per $\mathrm{kg}$ of N, P or K taken up by the crop, respectively (Nijhof 1987), a maize crop requires $34.1 \mathrm{~kg} \mathrm{~N} \mathrm{ha}{ }^{-1}, 9.4 \mathrm{~kg} \mathrm{P} \mathrm{ha}^{-1}$ and $30.9 \mathrm{~kg} \mathrm{~K} \mathrm{ha}{ }^{-1}$ to produce $3 \mathrm{t} \mathrm{ha}^{-1}$ of aboveground biomass. According to the calculated $S \mathrm{~N}, S \mathrm{P}$ and $S \mathrm{~K}$ maize production in our case study farms would be most often limited by $\mathrm{P}$ and $\mathrm{K}$ availability, with only a few points above the required $\mathrm{N}$ and $\mathrm{P}$ uptakes, whereas the required uptake of $\mathrm{N}$ would be met in soils with organic $\mathrm{C}>$ about $10 \mathrm{~g} \mathrm{~kg}^{-1}$ (Fig. 4b). These conclusions, however, are not supported by the actual $\mathrm{N}, \mathrm{P}$ and $\mathrm{K}$ uptakes measured in the R-M experiment, which indicate a much larger soil supply of these nutrients.

\section{Nutrient capture efficiency}

The apparent recovery efficiencies of applied N, P and $\mathrm{K}$ (Eq. 8) were calculated using data on nutrient concentrations in grain and stover from the R-M onfarm experiments (Table 4). The recovery efficiencies of the applied nutrients varied widely and were affected by the type and combination of nutrients applied and by the position of the field within the farm. No significant effect of locality, and no 
Fig. 4 a, $\mathbf{c}$ and $\mathbf{e}$ Uptake of $\mathrm{N}, \mathrm{P}$ and $\mathrm{K}$ in grain in the control and in fertilised plots versus the soil supply of N, P and $\mathrm{K}(S \mathrm{~N}, S \mathrm{P}$ and $S K$, respectively) calculated using the formulas of QUEFTS (Eqs. 1, 2 and 3 in the text-Janssen et al. 1990) for all the fields included in the nutrientomission experiment. b, d and $\mathbf{f} S \mathrm{~N}, S \mathrm{P}$ and $S \mathrm{~K}$ (black dots) plotted against measured total soil N, extractable $\mathrm{P}$ and exchangeable $\mathrm{K}$ content in the topsoil of the experimental fields before the experiment, together with $\mathrm{N}, \mathrm{P}$ and $\mathrm{K}$ uptake in grain (grey dots) and total aboveground biomass (stars) in plots receiving fertilisers
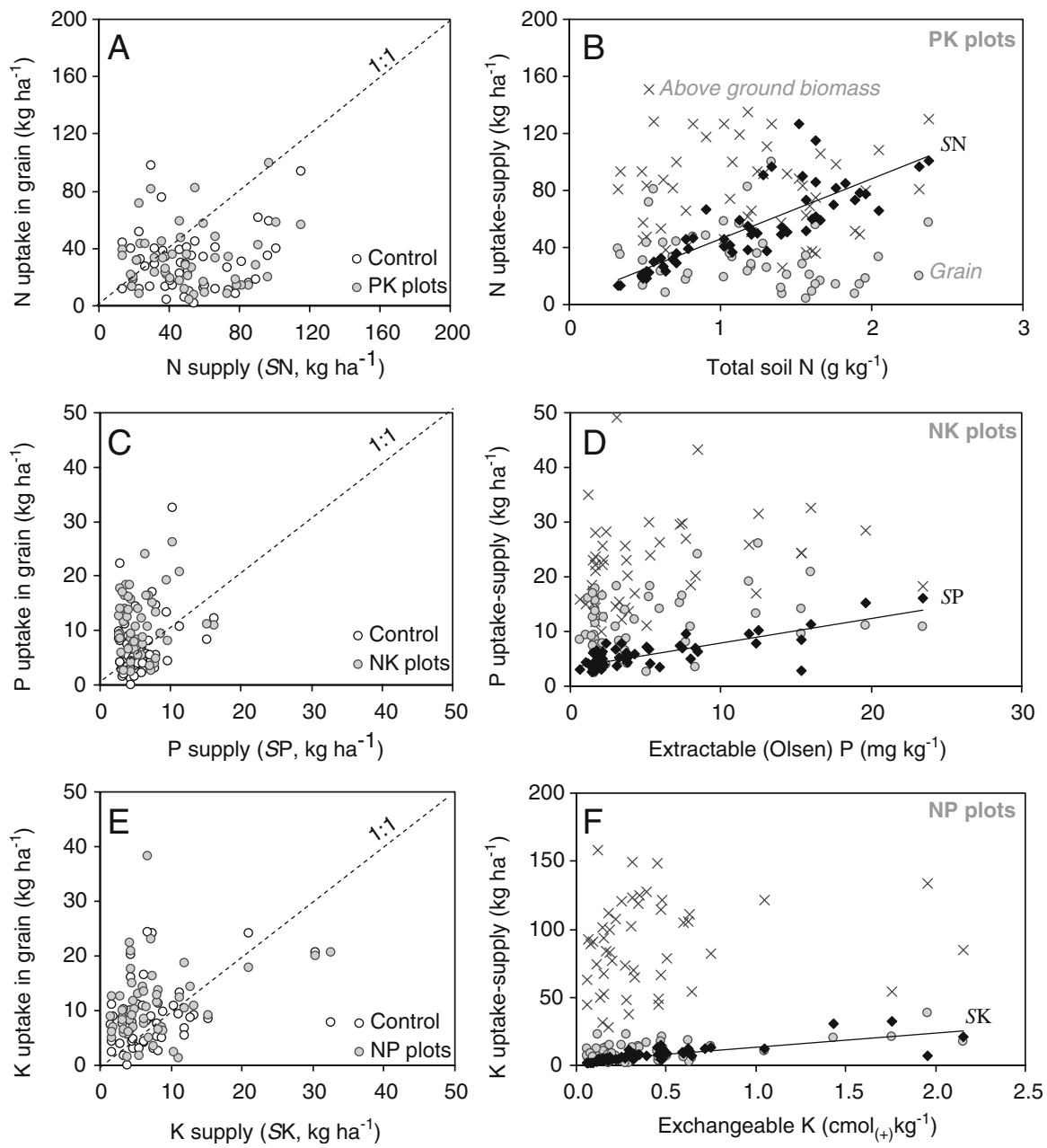

significant interaction locality $\times$ position within the farm were observed for any of the variables. The overall average recovery efficiencies across localities, positions within the farm and fertiliser applications (i.e. the grand means) were $0.40,0.06$ and 0.26 for $\mathrm{N}, \mathrm{P}$ and $\mathrm{K}$, respectively. For $\mathrm{N}$ and $\mathrm{P}$, these values are close to those used as default in QUEFTS (0.5 and 0.1 , respectively-Smaling and Janssen 1993). The maximum values for $\mathrm{N}$ recovery efficiencies (c. 0.6 to $0.7)$ were measured on R-M fields that received the full rate of N-P-K fertilisers (Table 4). In Emuhaya and Shinyalu, the $\mathrm{N}$ recovery efficiency was lower when no $\mathrm{P}$ was applied (i.e. for $\mathrm{N}-\mathrm{K}$ combinations). Across sites, $\mathrm{P}$ recovery was generally poorer when no $\mathrm{N}$ was applied (i.e. for $\mathrm{P}-\mathrm{K}$ combinations), while $\mathrm{K}$ recovery was affected by both $\mathrm{N}$ and $\mathrm{P}$, as both $\mathrm{N}-\mathrm{K}$ and $\mathrm{P}-\mathrm{K}$ combinations on average led to lower efficiencies than $\mathrm{N}-\mathrm{P}-\mathrm{K}$.

\section{Nutrient conversion efficiency}

$\mathrm{N}, \mathrm{P}$ and $\mathrm{K}$ conversion efficiencies (Eq. 9) were calculated from nutrient concentrations and biomass measurements on R-M fields (Fig. 5, Table 5). The theoretical minimum and maximum $\mathrm{N}, \mathrm{P}$ and $\mathrm{K}$ conversion efficiencies (i.e. their maximum concentration and dilution within the plant) as calculated from reference nutrient concentrations given by Nijhof (1987), are indicated by the lines in Figs. 5ac. These theoretical values encompass reasonably well the variability in observed nutrient uptake and aboveground biomass yield on the R-M plots. While measured $\mathrm{N}$ and $\mathrm{K}$ conversion efficiencies were closer to their maximum theoretical concentrations in the plant (Figs. 5a and c), P was often more diluted, with values closer to its minimum theoretical concentration (Fig. 5b). In general, the conversion efficien- 
Table 4 Average N, P and K uptake by maize on the control plots (without fertilizers) and apparent N, P and K recovery fractions for different combinations of mineral fertilizer applications measured on the R-M plots

\begin{tabular}{|c|c|c|c|c|c|c|c|c|c|c|c|c|}
\hline \multirow{2}{*}{$\begin{array}{l}\text { Locality and position } \\
\text { within the farm }\end{array}$} & \multicolumn{3}{|c|}{ Nutrient uptake $\left(\mathrm{kg} \mathrm{ha}^{-1}\right)$} & \multicolumn{3}{|c|}{ Apparent $\mathrm{N}$ recovery } & \multicolumn{3}{|c|}{ Apparent $\mathrm{P}$ recovery } & \multicolumn{3}{|c|}{ Apparent $\mathrm{K}$ recovery } \\
\hline & $\mathrm{N}$ & $\mathrm{P}$ & $\mathrm{K}$ & NPK & NP & NK & NPK & NP & PK & NPK & NK & PK \\
\hline \multicolumn{13}{|l|}{ Aludeka } \\
\hline Homefields & 99 & 25 & 93 & 0.21 & 0.32 & 0.10 & 0.06 & 0.03 & 0.05 & 0.40 & 0.18 & 0.35 \\
\hline Midfields & 57 & 11 & 66 & 0.69 & 0.40 & 0.59 & 0.15 & 0.15 & 0.04 & 0.52 & 0.41 & 0.02 \\
\hline Outfields & 60 & 14 & 76 & 0.55 & 0.68 & 0.38 & 0.12 & 0.14 & 0.00 & 0.41 & 0.02 & -0.10 \\
\hline Mean & 72 & 17 & 79 & 0.48 & 0.46 & 0.36 & 0.11 & 0.11 & 0.03 & 0.44 & 0.20 & 0.09 \\
\hline \multicolumn{13}{|l|}{ Emuhaya } \\
\hline Homefields & 87 & 17 & 83 & 0.70 & 0.39 & 0.26 & 0.07 & 0.02 & 0.02 & 0.50 & 0.18 & 0.02 \\
\hline Midfields & 74 & 11 & 46 & 0.60 & 0.58 & 0.35 & 0.10 & 0.08 & 0.05 & 0.45 & 0.53 & 0.18 \\
\hline Outfields & 56 & 10 & 40 & 0.64 & 0.33 & 0.25 & 0.07 & 0.07 & 0.06 & 0.35 & 0.11 & 0.42 \\
\hline Mean & 72 & 13 & 56 & 0.65 & 0.43 & 0.29 & 0.08 & 0.06 & 0.04 & 0.43 & 0.27 & 0.21 \\
\hline \multicolumn{13}{|l|}{ Shinyalu } \\
\hline Homefields & 102 & 15 & 99 & 0.38 & 0.35 & 0.17 & 0.06 & 0.03 & 0.00 & 0.40 & 0.57 & -0.06 \\
\hline Midfields & 73 & 13 & 75 & 0.48 & 0.58 & 0.23 & 0.05 & 0.09 & -0.02 & 0.40 & 0.06 & -0.03 \\
\hline Outfields & 50 & 8 & 51 & 0.28 & 0.45 & 0.00 & 0.04 & 0.07 & 0.01 & 0.28 & -0.04 & 0.02 \\
\hline Mean & 75 & 12 & 75 & 0.38 & 0.46 & 0.14 & 0.05 & 0.07 & 0.00 & 0.36 & 0.20 & -0.02 \\
\hline SED & 10.5 & 2.3 & 12.0 & 0.14 & 0.13 & 0.13 & 0.03 & 0.03 & 0.02 & 0.16 & 0.17 & 0.13 \\
\hline
\end{tabular}

$S E D$ standard error of the difference

cies of $\mathrm{N}, \mathrm{P}$ and $\mathrm{K}$ were less variable across localities, fields and fertilisation treatments than the corresponding recovery efficiencies (cf. Tables 4 and 5). The overall average conversion efficiencies across localities, positions within the farm and fertilisation treatments were $97 \mathrm{~kg} \mathrm{DM} \mathrm{kg}^{-1} \mathrm{~N}, 558 \mathrm{~kg} \mathrm{DM} \mathrm{kg}^{-1} \mathrm{P}$ and $111 \mathrm{~kg} \mathrm{DM} \mathrm{kg}^{-1} \mathrm{~K}$ taken up. The average $\mathrm{N}$, $\mathrm{P}$ and $\mathrm{K}$ conversion efficiencies were significantly $(P<0.05,0.01$ and 0.01 , respectively) larger in Emuhaya than in the other localities, and nutrients tended to be on average more diluted in the crop biomass on control plots than on fertilised plots. $\mathrm{N}$ and $\mathrm{P}$ uptake and their conversion efficiencies (Figs. 5a and $b$ ) are within similar ranges as those measured for maize in on-farm experiments conducted on clayey and sandy soils in Zimbabwe (Zingore et al. 2007), including different positions within the farm and different rates of mineral $\mathrm{N}$ and $\mathrm{P}$ and manure applications. In the Zimbabwean case, however, $\mathrm{N}$ and $\mathrm{P}$ concentrations were somewhat closer to their maximum (more concentrated) than in this case.

Predicting maize yields from soil nutrient availability

Yields on F-M plots were first contrasted against yields predicted by QUEFTS for the same plots.
Results are illustrated in Fig. 6 only for Aludeka, where two highly contrasting soil types known locally as Apokkor (clay loam) and Assinge (sand loam to sand) coexist, and only the yields on the F-M plots that did not receive nutrient inputs are considered. Maize yields on F-M plots without nutrient inputs were poorly predicted by QUEFTS $\left(r^{2}=0.22\right.$, RMSE $=0.53 \mathrm{t} \mathrm{ha}^{-1}$ ) for Aludeka (Fig. 6a), as well as for the other localities (Emuhaya, $r^{2}=0.29$, RMSE= $1.8 \mathrm{t} \mathrm{ha}^{-1}$; Shinyalu, $r^{2}=0.05$, RMSE $=1.7 \mathrm{t} \mathrm{ha}^{-1}$ ). The model was however sensitive to differences in fertility between the two soil types (Fig. 6b). The simulated N-P-K applications (100:100:100 kg element $\mathrm{ha}^{-1}$ ) indicated strong response to $\mathrm{N}$ and secondarily to $\mathrm{P}$, in agreement with previous observations in the vicinity of Aludeka (Alupe Experimental StationFURP 1994), and maximum yields which were within the range of the maximum yields measured in F-M fields in Aludeka (cf. Table 3).

The estimated average gap between yields measured under F-M and QUEFTS-predicted yields under full N-P-K was 2.9 and $2.5 \mathrm{t} \mathrm{ha}^{-1}$ for Apokkor and Assinge soils, respectively (Fig. 6b). The responses to applied nutrients predicted by QUEFTS are affected by the value of the yield potential $\left(Y_{\max }\right)$ that is inputted as parameter. In this case, however, the 

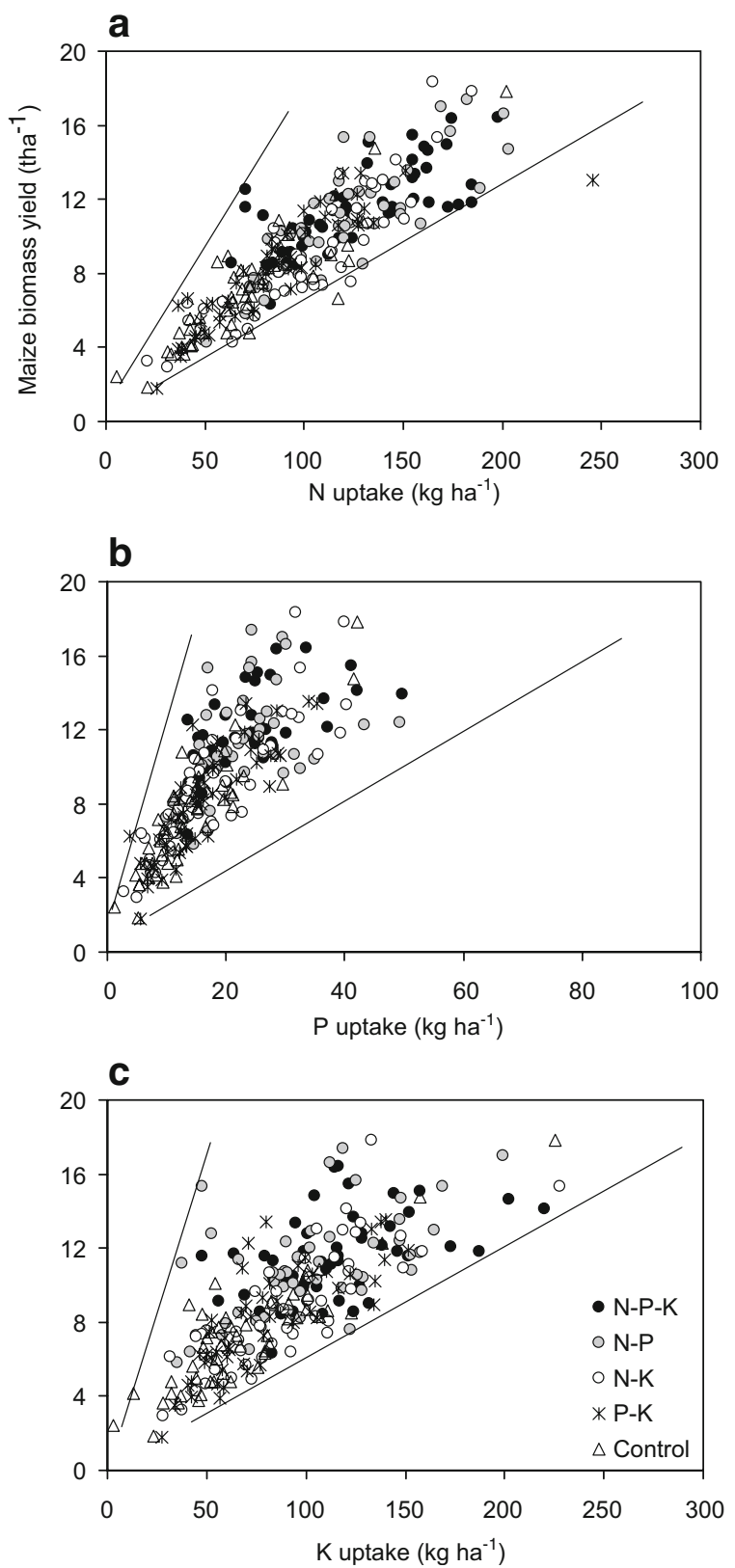

Fig. 5 The relationship between crop N, P and K uptake and aboveground biomass yield measured in all plots of the on-farm $\mathrm{R}-\mathrm{M}$ experiment. Upper and lower boundary lines indicate the physiological maximum dilution and concentration of each nutrient in plant biomass (Nijhof 1987)

average relative partial sensitivity (relative change in model output, grain yield, over the relative change in model input parameter, $Y_{\max }$ ) to changes in $Y_{\max }$ between 6 and $14 \mathrm{tha}^{-1}$ was only 0.0003 when the application rate was 90:30:0, 0.01 for 100:100:100, 0.19 for 200:200:200 kg ha $\mathrm{kg}^{-1}$ and 0.46 for
300:300:300 $\mathrm{kg} \mathrm{ha}^{-1}$. Due to severe nutrient limitations for maize in the soils of our study the N-, P- and Klimited maize yields calculated by the model remained far below $Y_{\max }$ for the application rates tested in this study, and therefore the model was not sensitive to this parameter.

The lack of agreement between QUEFTS-predicted and observed yields in Fig. 6a is not surprising, given the various sources of variability that affect maize production under F-M. Observed maize yields under F-M without fertilisers tended to increase with increasing soil organic $\mathrm{C}$ and available $\mathrm{P}$ (Figs. 5c and d), whereas late planting and sparse plant population densities led to poorer yields (Figs. 5e and f). Maize yields predicted by QUEFTS tended to follow similar trends with respect to these soil fertility and management factors (the lines fitted to the QUEFTS-predicted maize yields had $r^{2}$ values of 0.40 for soil $\mathrm{C}, 0.12$ for available $\mathrm{P}, 0.45$ for delay in planting and 0.16 for plant density). While it is expected that QUEFTS predicts larger yields for soils with higher $\mathrm{C}$ and $\mathrm{P}$ contents, the trends in predicted yields with agronomic management variables are not directly related to the basis of the model (i.e. planting dates and plant density are not considered as parameters in QUEFTS). The reason for the simulated patterns is the fact that soil fertility and management decisions are correlated; e.g. farmers plant earlier and with a higher plant density on the more fertile fields.

Subsequently, we used QUEFTS to explore the yields that could be attained with fertiliser applications on the R-M plots. QUEFTS-predicted yields were contrasted against measured ones. The root mean squared error (RMSE) between predicted and measured yields were rather large (e.g., $\mathrm{RMSE}_{\mathrm{control}}=$ $1.53 \mathrm{tha}^{-1} ; \mathrm{RMSE}_{\mathrm{NPK}}=2.83 \mathrm{t} \mathrm{ha}^{-1}$ ) in relation to the average yields measured (cf. Table 3) when the default values for fertiliser recovery efficiencies were used. The calculations were re-done using the fertiliser recovery efficiencies that we observed as model input (cf. Table 4) and the prediction of yields with fertiliser improved (e.g., the new $\mathrm{RMSE}_{\mathrm{NPK}}=$ $1.88 \mathrm{tha}^{-1}$ ). With this new parameterisation, we used QUEFTS to calculate grain yields with application of $30 \mathrm{~kg} \mathrm{P} \mathrm{ha}{ }^{-1}$ and $30 \mathrm{~kg} \mathrm{P} \mathrm{ha}^{-1}$ plus $90 \mathrm{~kg} \mathrm{~N} \mathrm{ha}^{-1}$ (Fig. 7). The response to $30 \mathrm{~kg} \mathrm{P} \mathrm{ha}{ }^{-1}$ increased with increasing soil $\mathrm{C}$, as evidenced by steeper slope of the trend lines describing simulated grain yield with 
Table 5 N, P and K conversion efficiencies calculated from plant nutrient concentrations and biomass measured on the R-M plots

\begin{tabular}{|c|c|c|c|c|c|c|c|c|c|c|c|c|c|c|c|}
\hline \multirow[t]{2}{*}{$\begin{array}{l}\text { Locality and position } \\
\text { within the farm }\end{array}$} & \multicolumn{5}{|c|}{$\begin{array}{l}\mathrm{N} \text { conversion efficiency } \\
\left(\mathrm{kg} \mathrm{DM} \mathrm{kg}^{-1} \mathrm{~N}\right)\end{array}$} & \multicolumn{5}{|c|}{$\begin{array}{l}\text { P conversion efficiency } \\
\left(\mathrm{kg} \mathrm{DM} \mathrm{kg}^{-1} \mathrm{P}\right)\end{array}$} & \multicolumn{5}{|c|}{$\begin{array}{l}\text { K conversion efficiency } \\
\left(\mathrm{kg} \mathrm{DM} \mathrm{kg}^{-1} \mathrm{~K}\right)\end{array}$} \\
\hline & Control & NPK & $\mathrm{NP}$ & NK & PK & Control & NPK & NP & NK & PK & Control & NPK & $\mathrm{NP}$ & NK & PK \\
\hline \multicolumn{16}{|l|}{ Aludeka } \\
\hline Homefields & 99 & 100 & 92 & 101 & 97 & 397 & 418 & 434 & 456 & 377 & 105 & 93 & 110 & 107 & 88 \\
\hline Midfields & 112 & 98 & 100 & 83 & 105 & 577 & 463 & 399 & 395 & 502 & 98 & 103 & 86 & 95 & 105 \\
\hline Outfields & 110 & 95 & 95 & 94 & 102 & 458 & 434 & 487 & 550 & 465 & 89 & 95 & 117 & 106 & 98 \\
\hline Mean & 107 & 98 & 95 & 93 & 101 & 478 & 438 & 440 & 467 & 448 & 97 & 97 & 104 & 102 & 97 \\
\hline \multicolumn{16}{|l|}{ Emuhaya } \\
\hline Homefields & 112 & 92 & 92 & 95 & 94 & 593 & 572 & 576 & 572 & 505 & 134 & 102 & 144 & 102 & 115 \\
\hline Midfields & 98 & 92 & 90 & 105 & 93 & 674 & 589 & 634 & 706 & 613 & 148 & 143 & 196 & 109 & 140 \\
\hline Outfields & 165 & 104 & 103 & 82 & 106 & 885 & 677 & 552 & 665 & 585 & 284 & 154 & 106 & 137 & 104 \\
\hline Mean & 125 & 96 & 95 & 94 & 98 & 717 & 613 & 587 & 647 & 568 & 189 & 133 & 149 & 116 & 120 \\
\hline \multicolumn{16}{|l|}{ Shinyalu } \\
\hline Homefields & 97 & 86 & 85 & 87 & 94 & 650 & 567 & 641 & 587 & 585 & 99 & 87 & 118 & 71 & 96 \\
\hline Midfields & 92 & 88 & 88 & 78 & 119 & 548 & 598 & 528 & 604 & 815 & 94 & 92 & 95 & 93 & 113 \\
\hline Outfields & 93 & 103 & 84 & 85 & 91 & 566 & 647 & 532 & 571 & 462 & 88 & 99 & 89 & 89 & 81 \\
\hline Mean & 94 & 92 & 86 & 83 & 101 & 588 & 604 & 567 & 587 & 621 & 93 & 93 & 101 & 84 & 97 \\
\hline \multicolumn{16}{|c|}{ Standard error of the differences between averages of } \\
\hline Site & & & 4.3 & & & & & 24.4 & & & & & 7.1 & & \\
\hline Position within the farm & & & 4.3 & & & & & 24.4 & & & & & 7.1 & & \\
\hline Fertilisation treatment & & & 5.6 & & & & & 31.5 & & & & & 9.2 & & \\
\hline \multicolumn{16}{|c|}{ ANOVA-Significance for the effects of } \\
\hline Site & & & $*$ & & & & & $* *$ & & & & & $* *$ & & \\
\hline Position within the farm & & & Ns & & & & & Ns & & & & & Ns & & \\
\hline Fertilisation treatment & & & $* *$ & & & & & Ns & & & & & $*$ & & \\
\hline
\end{tabular}

All interactions non-significant except site $\times$ fertilisation treatment $(P<0.05)$ for $\mathrm{P}$ conversion efficiency.

Ns not significant

$30 \mathrm{~kg} \mathrm{P} \mathrm{ha}{ }^{-1}$ compared with the control in Fig. 7. This is in agreement with the observed relationship between soil $\mathrm{C}$ and available $\mathrm{P}$ (cf. Fig. 2), which points to the existence of non-P-responsive and Presponsive fields. When $\mathrm{P}$ was added in combination with $\mathrm{N}$, yields increased also on plots with $<10 \mathrm{~g} \mathrm{~kg}^{-1}$ of soil organic $\mathrm{C}$, and the distribution of yields against soil $\mathrm{C}$ was more dispersed $\left(r^{2}=0.31\right)$. According to these model predictions, there is room to increase maize yields of poor fields by combined application of $\mathrm{N}$ and $\mathrm{P}$ fertilisers.

Fertiliser/maize price ratios

As reference for the interpretation of fertilizer use efficiencies and maize responses presented in the previous sections, we calculated the fertilizer/grain price ratio (i.e., the $\mathrm{kg}$ of grain necessary to buy $1 \mathrm{~kg}$ of fertilizer), using varying wholesale and retail prices for calcium ammonium nitrate (CAN) fertilizer and maize grain, based on prices from market surveys in western Kenya (Table 6). The most favorable ratio (of $2.2 \mathrm{~kg}$ grain to pay for each $\mathrm{kg} \mathrm{N}$ ) could be achieved by 'wealthier' farmers who produce maize surplus that can be sold locally (retail price) in times of food scarcity and who can buy a full $50 \mathrm{~kg}$-bag of fertilizer from (often distant, semi-) urban markets at more convenient prices. The worst ratio $(17.6 \mathrm{~kg}$ grain to pay for each $\mathrm{kg} \mathrm{N}$ ) is often faced by most farmers in remote rural settings, when cash needs force them to sell their maize at the lowest price immediately after harvest (and to buy maize at other times of the year), and when small amounts of fertilizers are bought from local retailers (also often the wealthiest farmers in the community) at high prices. Such inequalities imply that fertilizer use is 8 times more profitable for wealthier than for poorer farmers. 
Fig. 6 a Comparison between measured maize yields under farmers' management (F-M) without nutrient inputs vs. yields QUEFTS-predicted yields without fertilisers for Aludeka (solid trend line and dashed 1:1 line). b Measured F-M yields without nutrient inputs and QUEFTS-predicted yields with application of $\mathrm{N}, \mathrm{P}$ and $\mathrm{K}$ fertilisers at $100 \mathrm{~kg} \mathrm{ha}^{-1}$ each for the two main soil types found in Aludeka (Apokkor: Acrisols, Assinge: Lixisols) - vertical lines indicate standard deviation. Yields under F-M without inputs and QUEFTSpredicted yields without fertilisers plotted against $\mathbf{c}$ soil organic $\mathrm{C}$, d extractable $\mathrm{P}$, e days of delay in planting and $\mathbf{f}$ plant population densities. In $\mathrm{C}-\mathrm{F}$ the solid lines describe the trend in measured values, the dashed ones the QUEFTS-predicted values
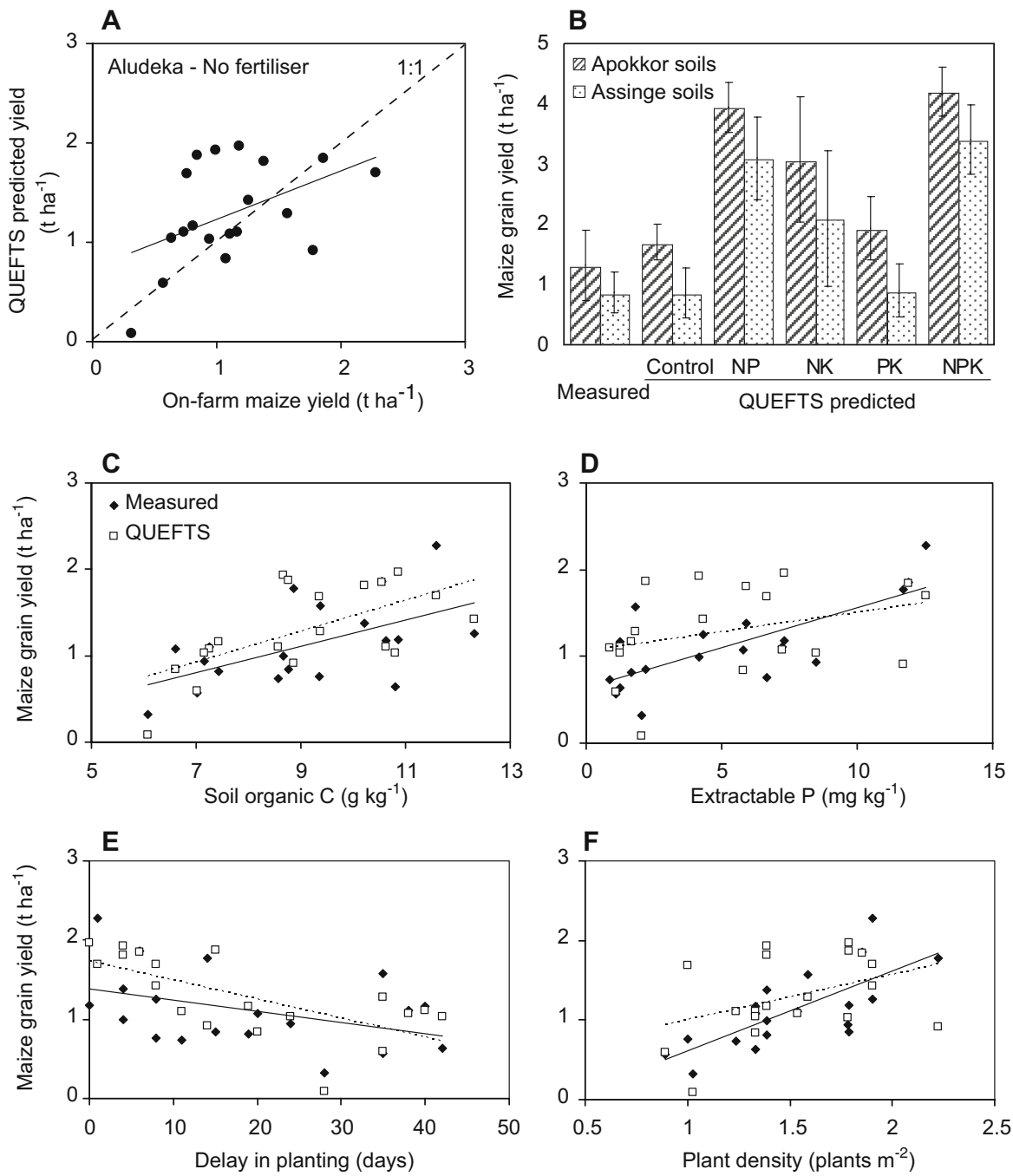

\section{Discussion}

The application of mineral fertilisers tended to narrow the differences in average maize yields across the various fields of the farms (from the home- to the outfields) included in the on-farm experiments in three localities of western Kenya (cf. Table 3). One of the most striking results observed in this study, however, was the gap between the average yields under farmers' management (F-M) - with or without nutrient inputs - and the average yields on researchermanaged (R-M) control plots without fertilisers. Experimental R-M plots were planted early in the season, with proper plant population densities, early weeding and pest/disease control, and using hybrid seeds. These management practices sufficed in several cases to more than double maize yields with respect to those attained by farmers. Maize yields under R-M were further increased in about $1 \mathrm{t} \mathrm{ha}^{-1}$ with respect to the control with application of $\mathrm{N}-\mathrm{P}-\mathrm{K}$ mineral fertilisers. Under F-M, the difference in average maize yields between plots receiving or not nutrient inputs ranged between 0.4 and $1.1 \mathrm{t} \mathrm{ha}^{-1}$, irrespective of the type and amount of inputs used (Fig. 1). This means that the average yields with nutrient inputs under F-M were below or at the same level as those on R-M control plots without fertilisers (cf. Fig. 1 and Table 3).

The above observations imply that the promotion of mineral fertiliser use in smallholder farming systems should go hand-in-hand with the implementation of measures to improve fertiliser use efficiency. We observed a wide variability in nutrient recovery 


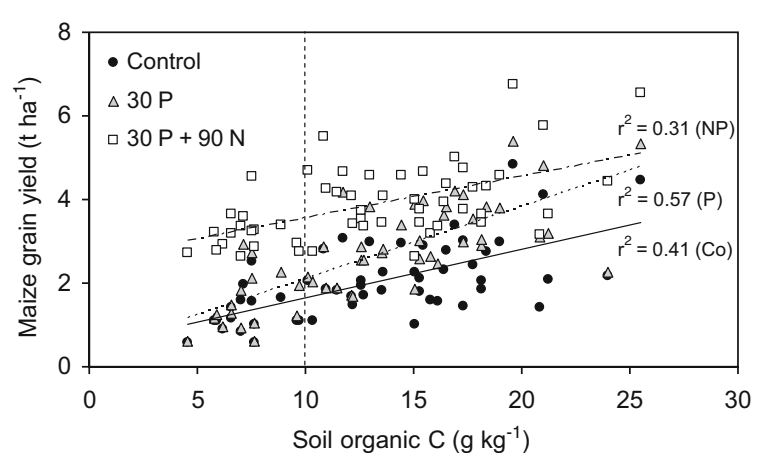

Fig. 7 Predicted maize responses to applied $\mathrm{P}$ and $\mathrm{N}$ fertilisers $\left(30 \mathrm{P}=30 \mathrm{~kg} \mathrm{P} \mathrm{ha}{ }^{-1} ; 30 \mathrm{P}+90 \mathrm{~N}=30 \mathrm{~kg} \mathrm{P} \mathrm{ha}^{-1}\right.$ plus $90 \mathrm{~kg} \mathrm{~N}$ $\mathrm{ha}^{-1}$ ) using QUEFTS with $\mathrm{N}, \mathrm{P}$ and $\mathrm{K}$ recovery efficiencies as measured in the experiment; predicted yields plotted against soil organic $\mathrm{C}$. The trend lines correspond to control (solid line), $30 \mathrm{P}$ (dashed line) and $30 \mathrm{P}+90 \mathrm{~N}$ (dot-dashed line). The vertical dotted line indicates the threshold of $10 \mathrm{~g} \mathrm{~kg}^{-1}$ of soil C

efficiencies (Table 4) across heterogeneous farms that may lead to very poor crop responses to applied fertilisers (Fig. 3). The apparent recovery of $\mathrm{P}$ and $\mathrm{K}$ applied in fertilisers was as low as $1-3 \%$ in several cases (Table 4). The recovery or capture of applied and indigenous soil nutrients are often affected by resource imbalances (Kho 2000), as when, for example, lack of $\mathrm{P}$ limits plant growth and prevents uptake of applied N or K. Poor capture and utilisation of available nutrients leads to wide yield gaps for maize in western Kenya. Yields measured earlier in on-station trials were still 2 to $3 \mathrm{t} \mathrm{ha}^{-1}$ larger than those measured in NPK plots under R-M (the yields from on-station trials presented in Table 3 were reported for a different growing season and presumably using different maize cultivars, which may contribute to widening or narrowing the actual yield gaps). At the other extreme, fertile fields such as the home gardens may also be poorly responsive to applied fertilisersa case of 'saturated soil fertility' (Janssen and de Willingen 2006; cf. Fig. 3).

Fertiliser recommendations should be fine-tuned to target soil fertility 'niches' within heterogeneous farms, differentiating responsive fields where mineral fertilisers are likely to be more efficiently used from non-responsive fields that may need long-term rehabilitation through organic matter management. Larger yields achieved with fertilisers use may result in greater $\mathrm{C}$ and nutrient inputs to the soil through crop residues (when they are not removed from the fields after harvest) and roots, contributing to the build up of soil organic matter in the long term. Improved water capture through more infiltration and less run-off and erosion, improving water and nutrient holding capacity through increasing organic matter in sandy soils, improving availability of applied and native soil nutrients through $\mathrm{pH}$ correction, and improved cultivars and agronomic management (e.g., early planting, weeding, etc.) are measures that can contribute to improve baseline crop productivity and the response to fertilisers, impacting mostly on their recovery efficiency. Animal manure is a key nutrient resource used by farmers with cattle in western Kenya (Waithaka et al. 2006), and their limited amounts available to fertilise crops would be more efficiently used in combination

Table 6 Fertiliser/grain price ratios (kg maize necessary to pay for $1 \mathrm{~kg}$ fertiliser) calculated for varying wholesale and retail prices in western Kenya (Source TSBF 2007)

\begin{tabular}{|c|c|c|c|c|c|c|c|}
\hline \multicolumn{2}{|l|}{ Price of $\mathrm{N}$ fertilizer ${ }^{\mathrm{a}}$} & \multicolumn{3}{|c|}{ Price bag of maize $(90 \mathrm{~kg})^{\mathrm{b}}$} & \multicolumn{3}{|c|}{ Price per goro goro $(2 \mathrm{~kg})^{\mathrm{c}}$} \\
\hline Bag of $50 \mathrm{~kg}$ (KSh) & Price per $\mathrm{kg} \mathrm{N}$ & 780 & 1,300 & 1,820 & 20 & 40 & 60 \\
\hline 1,530 & 67 & 7.7 & 4.6 & 3.3 & 6.7 & 3.3 & 2.2 \\
\hline 1,800 & 78 & 9.0 & 5.4 & 3.9 & 7.8 & 3.9 & 2.6 \\
\hline 2,070 & 90 & 10.4 & 6.2 & 4.5 & 9.0 & 4.5 & 3.0 \\
\hline \multicolumn{8}{|l|}{ Retailer $\left(\mathrm{KSh} \mathrm{kg}^{-1}\right)$} \\
\hline 50 & 109 & 12.5 & 7.5 & 5.4 & 10.9 & 5.4 & 3.6 \\
\hline 60 & 130 & 15.1 & 9.0 & 6.5 & 13.0 & 6.5 & 4.3 \\
\hline 70 & 152 & 17.6 & 10.5 & 7.5 & 15.2 & 7.6 & 5.1 \\
\hline
\end{tabular}

Prices (in Kenya Shillings, $1 \mathrm{KSh}=68 \mathrm{us \$}$ ) of fertilisers and maize fluctuate between rural and urban markets, and prices of maize also between periods of scarcity and abundance during the year.

${ }^{a}$ Calculated for calcium ammonium nitrate $(C A N)$; $\mathrm{N}$ content $46 \%$;

${ }^{\mathrm{b}}$ Prices of 780,1300 and 1820 are equivalent to 9,14 and $20 \mathrm{KSh} \mathrm{kg}^{-1}$ maize;

${ }^{\mathrm{c}}$ Local unit of trade, a tin of $\pm 2 \mathrm{~kg}$ maize; prices of 20, 40 and 60 are equivalent to 10,20 and $30 \mathrm{KSh} \mathrm{kg}^{-1} \mathrm{maize}$ 
with mineral fertilisers. Several examples in the literature report complementarities and/or synergies between both resources translating in larger crop responses (e.g. Bationo et al. 2006; Tittonell et al. 2008).

Fine-tuning fertiliser recommendations requires a framework for communication between researchers, extension agents and farmers. Soil heterogeneity must be categorised and each category of soil fertility status must be easily recognisable. Approaches based on local soil quality indicators (e.g. Barrios et al. 2006) are sometimes useful but difficult to generalise across agro-ecological zones. The use of local soil classification faces the same type of scale-related limitations as the use of soil maps or agroecological zones (e.g., Smaling et al. 1992), since different local soil names normally identify inherently different soil types (e.g. Ingusi and Oluyekhe are names used for red clayey and brown sandy soils in Emuhaya-Tittonell et al. 2005b) without considering the current fertility status of the soil units. Farmers often classify their fields into fertile and infertile based on their own experience about past and present crop productivity, history of management and land degradation events (e.g. Mairura et al. 2007). Their criteria were also used in the selection of fields in which the R-M experimental plots were established (Table 2).

Farmers' soil quality classes often reflect differences in the current content of organic matter in the soil, which is the result of inherent soil properties (e.g. texture) and management history (e.g. use of animal manure, years under cultivation/fallow, etc.). They may, however, not discriminate between P (and/ or $\mathrm{K}$ ) responsive and non-responsive soils. Our study indicates that soil organic $\mathrm{C}$ and available $\mathrm{P}$ co-vary within farms as induced by farmers' management practices (Fig. 2). A simple framework, based on the contents of organic carbon and available P in the soil, categorises fields that may be: poorly-responsive fertile fields [quadrant (1)], poorly-responsive infertile fields [quadrant (2)], and responsive medium-fertile to infertile fields [quadrant (3)]. Such patterns of responsiveness to applied fertilisers were observed earlier in on-farm experiments conducted in Zimbabwe (Zingore et al. 2007), where the differences in crop responses across fields were larger due to the coarser texture of the soils. Simple modelling tools such as QUEFTS may be useful for exploring responses to fertilisers across heterogeneous farms (Fig. 7). However, considering only soil nutrient availability and soil chemical properties does not seem to suffice for predicting on-farm crop responses to applied fertilisers (Fig. 6), due to the number of other factors affecting crop yields in farmers' fields that are not considered in the model (e.g., water availability, weed competition, intercrops, use of organic nutrient sources, etc.).

Across the various agro-ecological zones of western Kenya smallholder farms are highly heterogeneous and socially diverse. Fertiliser recommendations should then be tailor-made to target such variability. Farmers of different social status may access fertilisers at different actual prices (cf. Table 6), implying that the risk of the practice of fertilisation is much larger for poorer farmers. Ojiem et al. (2006) developed the concept of 'socio-ecological niches' for the integration of legumebased technologies in smallholder farming systems of western Kenya. Opportunities for different technology options including fertilizer use can be represented as a multi-dimensional space (niche) delimited by several criteria, which include farmers' production objectives, characteristics of the biophysical and socio-economic environments, and various locality-specific and organisational support factors, e.g. market development, technology support services. The latter two are major factors constraining the adoption of fertiliser-based technologies in western Kenya (Barrett et al. 2002). In view of the limited support provided by agricultural extension services, market accessibility and (transaction) costs, and the large variability in crop responses to fertilisers that can be expected in heterogeneous farms (cf. Figs. 3a-h), the limited use of mineral fertilisers currently observed in smallholder farms of western Kenya (e.g. an average of $20 \mathrm{~kg} \mathrm{~N}^{-1}$ for fields that do receive fertilisers-Tittonell et al. 2005b) is therefore not surprising.

\section{Conclusions}

The gap between attainable and actual maize yields in western Kenya, which is partly demonstrated by the yield gap between farmer- and researcher-managed plots, is associated with generalised poor resource use efficiency on farmers' fields. Resource use efficiencies are highly variable within and across heterogeneous farms, as a result of soil variability and farmers' management decisions, affecting crop responses to applied nutrients. Of the two components of nutrient use efficiency: capture and conversion efficiency, the 
former varies more broadly across fields, farms and agro-ecological zones. The major limitation to maize production in western Kenya, however, is not resource use efficiency but resource availability, and improving the availability of one resource may improve the utilisation of others. However, improving agronomic management reduced the gap between fertilised and non-fertilised maize crops substantially. Targeting mineral fertilisers to narrow the current yield gaps demands going beyond 'blanket recommendations', and considering the current heterogeneity in soil fertility status, resource use efficiency and crop response to fertilisers within smallholder farms. Poor crop responses to fertiliser applications discourage their adoption among farmers, for whom the transaction costs of fertilisers use may often render the practice too risky. Thus, paraphrasing the conclusions from the Abuja Fertiliser Summit, if the heterogeneity and diversity of smallholder farming systems are not recognised and embraced within fertiliser recommendations in subSaharan Africa, 'development will be hard to achieve even with fertilisers'.

Acknowledgements We thank the European Union for funding this research through the AfricaNUANCES Project (Contract no INCO-CT-2004-003729), the Rockefeller Foundation for providing financial support in the framework of the project on 'Valuing within-farm soil fertility gradients to enhance agricultural production and environmental service functions in smallholder farms in East Africa' (2003 FS036) and Bert Janssen for providing the model QUEFTS and discussing simulation results. We acknowledge the valuable comments of an anonymous reviewer.

Open Access This article is distributed under the terms of the Creative Commons Attribution Noncommercial License which permits any noncommercial use, distribution, and reproduction in any medium, provided the original author(s) and source are credited.

\section{References}

Anderson JM, Ingram JSI (1993) Tropical soil biology and fertility: a handbook of methods. CAB International, Wallingford, UK, p 221

Barrios E, Delve RJ, Bekunda M, Mowo J, Agunda J, Ramisch J, Trejo MT, Thomas RJ (2006) Indicators of soil quality: A South-South development of a methodological guide for linking local and technical knowledge. Geoderma 135:248-259

Barrett CB, Place F, Abdou A, Brown DR (2002) The challenge of stimulating adoption of improved natural resource management practices in African agriculture. In: Barrett CB, Place F, Abdou A (eds) Natural resources management in African agriculture-understanding and improving current practices. CABI Publishing, Wallingford, UK, pp 1-22

Bationo A, Kihara J, Vanlauwe B, Waswa B, Kimetu J (2006) Soil organic carbon dynamics, functions and management in West African agro-ecosystems. Agric Syst 97:13-25

Benson TD (1997) Annotated bibliography of past work on area-specific fertiliser recommendations for maize in Malawi. In: Benson TD, Kumwenda JDT (eds) Maize commodity team - annual report for the 1995/96 season. Ministry of Agriculture and Livestock Development, Department of Agricultural Research, Chitedze Agricultural Research Station. Lilongwe, Malawi, pp 122-134

Dobermann A, Witt C, Abdulrachman S, Gines HC, Nagarajan R, Son TT, Tan PS, Wang GH, Chien NV, Thoa VTK, Phung CV, Stalin P, Muthukrishnan P, Ravi V, Babu M, Simbahan GC, Adviento MA, Bartolome V (2003) Estimating indigenous nutrient supplies for site-specific nutrient management in irrigated rice. Agron J 95:924-935

FURP (1994) Final report of the fertiliser use recommendation program (FURP), volumes V and VII Busia and Kakamega districts. National Agricultural Research Laboratory-Kenya Ministry of Agriculture and Livestock, Nairobi, Kenya

Hassan RM (1998) Maize technology development and transfer: a GIS application for research planning in Kenya. CAB International, Wallingford, UK

IFDC (2003) An assessment of fertiliser prices in Kenya and Uganda: domestic prices vis-a - vis international market prices. IFDC Paper Series IFDC-PCD-27. IFDC, Muscle Shoals, USA

Jaetzold R, Schmidt H (1982) Farm management handbook of Kenya, vol. II: Natural conditions and farm management information. Part A: West Kenya. Kenya Ministry of Agriculture, Nairobi, Kenya

Janssen BH, Guiking FCT, van der Eijk D, Smaling EMA, Wolf J, Reuler H (1990) A system for quantitative evaluation of the fertility of tropical soils. Geoderma 46:299-318

Janssen BH, de Willingen P (2006) Ideal and saturated soil fertility as bench Marks in nutrient management. 1. Outline of the framework. Agric Ecosyst Environ 116:132-146

Kho RM (2000) On crop production and the balance of available resources. Agric Ecosyst Environ 81:223-223

Mairura FS, Mugendi DN, Mwanje JI, Ramisch JJ, Mbuga PK, Chianu JN (2008) Scientific evaluation of smallholder land use knowledge in central Kenya. Land Degrad Dev 19:77-90

Nijhof K (1987) The Concentration of Macro-elements in Economic Products and Residues of (Sub)Tropical Field Crops. Centre for World Food Studies, Staff working paper SWO-87-08, Wageningen, The Netherlands, p 52

Ojiem JO, de Ridder N, Vanlauwe B, Giller KE (2006) Socioecological niche: A conceptual framework for integration of legumes in smallholder farming systems. Int J Agric Sust 4:79-93

Pathak H, Aggarwal PK, Roetter R, Kalra N, Bandyopadhaya SK, Prasad S, van Keulen H (2003) Modelling the quantitative evaluation of soil nutrient supply, nutrient efficiency, and fertiliser requirements for wheat in India. Nutr Cycl Agroecosyst 65:105-113 
Rutunga V, Gachene CKK, Karanja NK, Palm CA (2003) Grain maize yield improvement using Tephrosia vogelii and Tithonia diversifolia biomass at Maseno, Kenya. Trop Subtrop Agroecosyst 2:1-11

Schnier HF, Recke H, Muchena FN, Muriuki AW (1997) Towards a practical approach to fertiliser recommendations for food crop production in smallholder farms in Kenya. Nutr Cycl Agroecosyst 47:213-226

Smaling EMA, Janssen BH (1993) Calibration of QUEFTS, a model predicting nutrient uptake and yields from chemical soil fertility indices. Geoderma 49:21-44

Smaling EMA, Nandwa SM, Prestele H, Roetter R, Muchena FN (1992) Yield response to fertilisers and manure under different agroecological conditions in Kenya. Agric Ecosyst Environ 41:241-252

Tittonell P, Vanlauwe B, Leffelaar PA, Giller KE (2005a) Estimating yields of tropical maize genotypes from nondestructive, on-farm plant morphological measurements. Agric Ecosyst Environ 105:213-220

Tittonell P, Vanlauwe B, Leffelaar PA, Shepherd KD, Giller KE (2005b) Exploring diversity in soil fertility management of smallholder farms in western Kenya. II. Within-farm variability in resource allocation, nutrient flows and soil fertility status. Agric Ecosyst Environ 110:166-184

Tittonell P, Vanlauwe B, de Ridder N, Giller KE (2007a) Heterogeneity of crop productivity and resource use efficiency within smallholder Kenyan farms: soil fertility gradients or management intensity gradients. Agric Syst 94:376-390

Tittonell P, Shepherd KD, Vanlauwe B, Giller KE (2007b) Unravelling factors affecting crop productivity in small- holder agricultural systems of western Kenya using classification and regression tree analysis. Agric Ecosyst Environ 123:137-150

Tittonell P, Corbeels M, van Wijk MT, Vanlauwe B, Giller KE (2008) Combining organic and mineral fertilizers for integrated soil fertility management in smallholder farming systems of Kenya - explorations using the crop-soil model FIELD. Agron J doi: 10.2134agronj2007.0355

Trenbath BR (1986) Resource use by intercrops. In: Francis CA (ed) Multiple cropping systems. Macmillan, New York, pp $57-79$

Vanlauwe B, Tittonell P, Mukalama J (2006) Within-farm soil fertility gradients affect response of maize to fertilizer application in western Kenya. Nutr Cycl Agroecosyst 76:171-182

Waithaka MM, Thornton PK, Herrero M, Shepherd KD (2006) Bio-economic evaluation of farmers' perceptions of viable farms in western Kenya. Agric Syst 90:243-271

Witt CA, Dobermann S, Gines HC, Guanghuo W, Nagarajan R (1999) Internal nutrient deficiencies in irrigated lowland rice of tropical and subtropical Asia. Field Crop Res 63:113-138

Wopereis MCS, Tamélokpo A, Ezui K, Gnakpénou D, Fofana B, Breman H (2006) Mineral fertilizer management of maize on farmer fields differing in organic inputs in the West African savanna. Field Crop Res 96:355-362

Zingore S, Murwira HK, Delve RJ, Giller KE (2007) Soil type, historical management and current resource allocation: three dimensions regulating variability of maize yields and nutrient use efficiencies on African smallholder farms. Field Crop Res 101:296-305 